\title{
Rural continental aerosol properties and processes observed during the Hohenpeissenberg Aerosol Characterization Experiment (HAZE2002)
}

\author{
N. Hock ${ }^{1}$, J. Schneider ${ }^{1}$, S. Borrmann ${ }^{1,2}$, A. Römpp ${ }^{3, *}$, G. Moortgat ${ }^{3}$, T. Franze ${ }^{4}$, C. Schauer ${ }^{4}$, U. Pöschl ${ }^{4, * *}$, \\ C. Plass-Dülmer ${ }^{5}$, and H. Berresheim ${ }^{5, * * *}$ \\ ${ }^{1}$ Particle Chemistry Dept., Max Planck Institute for Chemistry, Mainz, Germany \\ ${ }^{2}$ Institute for Atmospheric Physics, Johannes Gutenberg University, Mainz, Germany \\ ${ }^{3}$ Atmospheric Chemistry Dept., Max Planck Institute for Chemistry, Mainz, Germany \\ ${ }^{4}$ Institute of Hydrochemistry, Technical University of Munich, Germany \\ ${ }^{5}$ German National Meteorological Service (DWD), Observatory Hohenpeissenberg, Germany \\ *now at: Institute for Inorganic and Analytical Chemistry, Justus Liebig University Giessen, Germany \\ *** now at: Biogeochemistry Dept., Max Planck Institute for Chemistry, Mainz, Germany \\ **** now at: Dept. of Physics, National University of Ireland, Galway, Ireland
}

Received: 30 May 2007 - Published in Atmos. Chem. Phys. Discuss.: 21 June 2007

Revised: 3 January 2008 - Accepted: 7 January 2008 - Published: 8 February 2008

\begin{abstract}
Detailed investigations of the chemical and microphysical properties of rural continental aerosols were performed during the HAZE2002 experiment, which was conducted in May 2002 at the Meteorological Observatory Hohenpeissenberg (DWD) in Southern Germany.

Online measurements included: Size-resolved chemical composition of submicron particles; total particle number concentrations and size distributions over the diameter range of $3 \mathrm{~nm}$ to $9 \mu \mathrm{m}$; gas-phase concentration of monoterpenes, $\mathrm{CO}, \mathrm{O}_{3}, \mathrm{OH}$, and $\mathrm{H}_{2} \mathrm{SO}_{4}$. Filter sampling and offline analytical techniques were used to determine: Fine particle mass (PM2.5), organic, elemental and total carbon in PM2.5 (OC2.5, EC2.5, TC2.5), and selected organic compounds (dicarboxylic acids, polycyclic aromatic hydrocarbons, proteins).

Overall, the non-refractory components of submicron particles detected by aerosol mass spectrometry (PM1, $6.6 \pm 5.4 \mu \mathrm{g} \mathrm{m}^{-3}$, arithmetic mean and standard deviation) accounted for $\sim 62 \%$ of PM 2.5 determined by filter gravimetry $\left(10.6 \pm 4.7 \mu \mathrm{g} \mathrm{m}^{-3}\right)$. The relative proportions of nonrefractory submicron particle components were: $(23 \pm 39) \%$ ammonium nitrate, $(27 \pm 23) \%$ ammonium sulfate, and $(50 \pm 40) \%$ organics (OM1). OM1 was closely correlated with PM1 $\left(r^{2}=0.9\right)$ indicating a near-constant ratio of nonrefractory organics and inorganics.
\end{abstract}

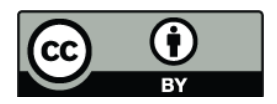

Correspondence to: J. Schneider (schneider@mpch-mainz.mpg.de)
The average ratio of OM1 to OC2.5 was $2.1 \pm 1.4$, indicating a high proportion of heteroelements in the organic fraction of the sampled rural aerosol. This is consistent with the high ratio of oxygenated organic aerosol (OOA) over hydrocarbon-like organic aerosol (HOA) inferred from the AMS results (4:1), and also with the high abundance of proteins $(\sim 3 \%)$ indicating a high proportion of primary biological material $(\sim 30 \%)$ in PM2.5. This finding was confirmed by low abundance of PAHs $\left(<1 \mathrm{ng} \mathrm{m}^{-3}\right)$ and EC $\left(<1 \mu \mathrm{g} \mathrm{m}^{-3}\right)$ in PM2.5 and detection of several secondary organic aerosol compounds (dicarboxylic acids) and their precursors (monoterpenes).

New particle formation was observed almost every day with particle number concentrations exceeding $10^{4} \mathrm{~cm}^{-3}$ (nighttime background level $1000-2000 \mathrm{~cm}^{-3}$ ). Closer inspection of two major events indicated that the observed nucleation agrees with ternary $\mathrm{H}_{2} \mathrm{SO}_{4} / \mathrm{H}_{2} \mathrm{O} / \mathrm{NH}_{3}$ nucleation and that condensation of both organic and inorganic species contributed to particle growth.

\section{Introduction}

Aerosol particles represent an important constituent of the Earth's atmosphere, since they influence the radiative balance, the chemical composition and the water cycle of the atmosphere. The radiative effects include the direct aerosol effects, i.e. the direct backscattering of incoming solar radiation into space, and the indirect effects due to the ability of aerosol particles to act as $\mathrm{CCN}$ (cloud condensation

Published by Copernicus Publications on behalf of the European Geosciences Union. 
nuclei) and thereby to alter cloud properties (e.g., Lohmann and Feichter, 2005; Penner et al., 2006; Yu et al., 2006; Stier et al., 2007). Furthermore, aerosol particles affect air quality and human health. Several studies showed a direct link between adverse effects on human health and fine particle $(d<2.5 \mu \mathrm{m})$ as well as ultrafine particles $(d<0.1 \mu \mathrm{m})$ (Oberdörster, 2001; Pope et al., 2002; Pope and Dockery, 2006).

A significant fraction of atmospheric aerosol particles are formed by gas-to-particle conversion (nucleation) of sulfuric acid, ammonia, water, and/or oxidized hydrocarbons (see review articles by Kulmala et al., 2004, and Curtius, 2006). The mentioned precursor compounds can be of anthropogenic or natural origin. While sulfuric acid has been identified in several experiments to trigger atmospheric nucleation (Berndt et al., 2005; Birmili et al., 2003; Birmili et al., 2000), the role of organic compounds is an open question (Bonn and Moortgat, 2002, 2003; Curtius, 2006).

The chemistry of atmospheric aerosols, especially their organic chemistry, is very complex, and the investigation of aerosol formation and atmospheric transformation processes is an ongoing challenge (e.g., Fuzzi et al., 2006; Kanakidou et al., 2005; Pöschl, 2005; Rogge et al., 1998; Seinfeld and Pankow, 2003). The above mentioned effects of aerosol particles on health, clouds, and climate depend both on the size (a physical property) and on the chemical composition of the aerosol particles.

A recent study by Dusek et al. (2006) suggested that variations of the chemical composition play only a minor role compared to particle size in $\mathrm{CCN}$ activation of continental aerosol particles, but this finding may not be generally applicable (Cubison et al., 2006; Broekhuizen et al., 2006; McFiggans et al., 2006; Hudson, 2007).

To achieve a better understanding of these atmospheric aerosol processes, it is essential to have size-resolved information on the chemical composition of the aerosol phase, besides many other aerosol properties. The large experimental setup that is needed to characterize the ambient aerosol can only be realized within intensive field studies. Such an intensive aerosol study, the Hohenpeissenberg Aerosol CharacteriZation Experiment (HAZE), was performed in May 2002 at the Meteorological Observatory Hohenpeissenberg (MOHp). The objective of this campaign was to perform a detailed study on physical and chemical properties of continental rural aerosol particles. The MOHp is located at a rural site about $40 \mathrm{~km}$ north of the Alps and surrounded by forest and agricultural pastures. In previous long-term measurements at $\mathrm{MOHp}$ the formation of new particles from gaseous precursors (in particular $\mathrm{H}_{2} \mathrm{SO}_{4}$ ) was observed quite frequently during spring but only rarely in summer (Birmili et al., 2000, 2003).

In the present paper we report on the results of the HAZE2002 study with respect to the chemical composition and size distribution of the aerosol phase, with emphasis on the organic composition inferred from mass spectrometry and filter analyses, comparison of the methods, mass closure, and the dependence of the aerosol properties on meteorological conditions as temperature and air mass origin.

\section{Experimental}

The HAZE2002 Experiment was conducted between 16 May 2002 and 30 May 2002 at the Meteorological Observatory Hohenpeissenberg $\left(47^{\circ} 48^{\prime} \mathrm{N}, 11^{\circ} 02^{\prime} \mathrm{E}, 985 \mathrm{~m}\right.$ a.s.l.) which is operated by Deutscher Wetterdienst (DWD) and is part of the Global Atmospheric Watch (GAW) program of the World Meteorological Organization (WMO). The observatory is located at about $300 \mathrm{~m}$ elevation above the surrounding area in a region with significant agricultural structure. A broad range of meteorological, trace gas, and aerosol parameters is continuously measured at $\mathrm{MOHp}$, among which are $\mathrm{H}_{2} \mathrm{SO}_{4}$ and $\mathrm{OH}$, measured by selected ion chemical ionization mass spectrometry (SI/CIMS) (Berresheim et al., 2000), number density of aerosol particles with $d>3 \mathrm{~nm}$ and $d>14 \mathrm{~nm}$ using condensation particle counters (CPC, models 3025A and 7610, TSI Inc., St. Paul, Minnesota) as well as monoterpenes and aromatic hydrocarbons which are monitored using gas chromatography - ion trap mass spectrometry (Birmili et al., 2003).

During the HAZE2002 campaign the following additional measurements were performed: The size distribution of ambient aerosol particles was measured with an optical particle counter (OPC PALAS model PCS 2010) for particles with diameters between $270 \mathrm{~nm}$ and $9.5 \mu \mathrm{m}$, and with a scanning mobility particle sizer (SMPS, models 3081 and 3085, TSI Inc.) for particle size ranges $7-300 \mathrm{~nm}$ and $3-65 \mathrm{~nm}$, respectively. The number density of aerosol particles with $d>3 \mathrm{~nm}$ was measured with an ultrafine condensation particle counter (UCPC, model 3025A, TSI Inc.). The sizeresolved chemical composition of non-refractory submicron aerosol particles was measured with the Aerodyne Q-AMS (Quadrupole Aerosol Mass Spectrometer) (Allan et al., 2003; Canagaratna et al., 2007; Jayne et al., 2000; Jimenez et al., 2003b). Q-AMS mass concentration and size distribution data were taken between 20 May 2002 and 30 May 2002, with a time resolution of $6 \mathrm{~min}$. For the calculation of ambient mass concentrations, a collection efficiency with respect to particle bounce from the vaporizer $(C E)$ of 0.5 was used (Alfarra et al., 2004; Allan et al., 2004a). Implications and errors that result from this assumption will be discussed in the following sections. The aerodynamic lens of the Q-AMS (Zhang et al., 2002, 2004) transmits particles in the size range (vacuum aerodynamic diameter, $d_{v a}$ ) from 50 to $600 \mathrm{~nm}$ with $100 \%$ efficiency. The transmission of the lens drops off significantly for $d_{v a}>1 \mu \mathrm{m}$, providing similar characteristics to $\mathrm{PM}_{1}$ size selective inlets used in filter based measurements (Weimer et al., 2006).

Filter samples of fine air particulate matter (PM2.5) were collected on $150 \mathrm{~mm}$ diameter glass fiber filters 
(Macherey-Nagel, MN 85/90 binder-free) with a high volume filter sampler (HVS; Digitel DHA 80, volumetric flow rate $500 \mathrm{~L} / \mathrm{min}$, sampling interval $24 \mathrm{~h}$ ). Prior to use, the filters were heated to $300^{\circ} \mathrm{C}$ for $12-18 \mathrm{~h}$ in a muffle furnace to remove organic contaminants. For gravimetric mass determination of the sampled particulate matter, the filters were conditioned at $45 \%$ relative humidity at room temperature $(295 \mathrm{~K})$ over saturated $\mathrm{K}_{2} \mathrm{CO}_{3}$-solution in a glass desiccator for 2 days before weighing. The weighing was performed at $(50 \pm 10) \% \mathrm{RH}$ and the weighing results were not significantly affected by uptake or loss of water during the weighing procedure, as confirmed by test experiments. After weighing on an analytical balance, the samples were wrapped in aluminum foil and stored at $-20^{\circ} \mathrm{C}$. The total carbon (TC2.5) and elemental carbon (EC2.5) contents of the aerosol filter samples have been determined with a thermochemical carbon analyzer (Stroehlein Coulomat 702). $\mathrm{TC}_{2.5}$ was measured by combustion of sample aliquots under $\mathrm{O}_{2}$ at $600^{\circ} \mathrm{C}$ and detection of the evolved $\mathrm{CO}_{2}$ by coulometric detection. For EC determination the sample aliquots were pre-conditioned by solvent extraction and thermal desorption prior to combustion; organic carbon (OC2.5) was determined as the difference between TC2.5 and EC2.5 (Schauer et al., 2004). Polycyclic aromatic hydrocarbons (PAH) were determined by high performance liquid chromatography with fluorescence detection (Schauer et al., 2004, 2003a, b). The PAH concentrations reported in this manuscript refer to the sum of 12 out of the 16 EPA PAH priority pollutants: phenanthrene, anthracene, fluoranthene, pyrene, benzo[a]anthracene, chrysene, benzo[b]fluoranthene, benzo[k]fluoranthene, benzo[a]pyrene, dibenz[ah]anthracene, benzo[ghi]perylene, indeno[1,2,3-cd]pyrene. Not included are the four EPA PAHs with lowest molecular mass and highest volatility (naphthalene, acenaphthene, acenaphthylene, fluorene).

Proteins were determined with a bicinchoninic acid assay calibrated with bovine serum albumin (Franze, 2004; Franze et al., 2005). The reported values have to be considered as equivalent concentrations which approximate the actual protein content of the samples but may be influenced by related macromolecular substances - e.g., humic or humic-like substances, respectively (Fehrenbach, 2006; Franze, 2004; Graber and Rudich, 2006; Ivleva et al., 2007).

On 22 May 2002 and 23 May 2002, filter samples were taken with a time resolution of $3 \mathrm{~h}$ during the day (08:00 to 20:00) and $12 \mathrm{~h}$ during the night (20:00 to 08:00 CEST) using an additional Digitel DA-80 high volume sampler, also equipped with a $2.5 \mu \mathrm{m}$ sampling head (calculated for a volumetric sample flow rate of $500 \mathrm{~L} \mathrm{~min}^{-1}$ ). The flow rate in this study was increased to $1000 \mathrm{~L} \mathrm{~min}^{-1}$ resulting in a cutoff size of $2.0 \mu \mathrm{m}$. The samples were analyzed for carboxylic acids with a LC/MS/MS-ToF instrument combining tandem mass spectrometry and high mass resolution measurements (Römpp, 2003). A regular reversed-phase HPLC system ( $2 \mathrm{~mm} \mathrm{C}_{18}$ colum) was coupled to a hybrid mass spectrome- ter (quadrupole and time-of-flight) QSTAR (Applied Biosystems MDS SCIEX, Toronto, Canada) by an electrospray ion source.

The Q-AMS as well as the SMPS, OPC and UCPC were set up in a laboratory in the top floor of the observatory on the southwestern side facing the dominant wind direction. The aerosol samplers were mounted outside on the roof platform of the building, and precautions were taken that the exhaust of the instrument did not affect the particle sampling. The particle inlet to the indoor instruments, a stainless steel tube with a length of $2 \mathrm{~m}$ and an inner diameter of $8 \mathrm{~mm}$, was designed to be near-isokinetic. Raindrops were prevented from entering the line by means of a downward facing funnel at the beginning of the line. The tube included one $90^{\circ}$-bend to transmit the particles to the Q-AMS as well as to the SMPS, $\mathrm{UCPC}$ and OPC. Ambient air was pumped through this tube with $25 \mathrm{~L} \mathrm{~min}^{-1}$, including a sample flow of $0.1 \mathrm{~L} \mathrm{~min}^{-1}$ of the Q-AMS. The transport losses of the sampling system with respect to inertia, diffusion and settling losses have been calculated based on simple aerodynamic calculations (Hinds, 1999). Averaged over the size ranges that are detected by the Q-AMS, the SMPS, the UCPC, and the OPC the total transport losses are smaller than $12 \%$.

\section{Results and discussion}

\subsection{Overview and aerosol mass closure}

Figure 1 gives an overview on the time series of several important parameters measured during the HAZE2002 project: Temperature, relative humidity, particle number density, $\mathrm{H}_{2} \mathrm{SO}_{4}$ concentration, particle number size distribution, mass concentrations of sulfate, nitrate, ammonium, organics, PM2.5, EC2.5, and OC2.5.

Panels (a) to (c) reveal that the temperature, the number concentration of total and ultrafine particles, and $\mathrm{H}_{2} \mathrm{SO}_{4}$ number concentration show a pronounced diurnal cycle, which is an indication for photochemical particle formation. This will be discussed in more detail in Sect. 3.4.

The mass concentrations measured with the Q-AMS data (Panels $\mathrm{d}$ and e) show a large variation, ranging between $3 \mu \mathrm{g} / \mathrm{m}^{3}$ to $13 \mu \mathrm{g} / \mathrm{m}^{3}$ (diurnal averaged concentration). All four species increase significantly between 21 May 2002 and 23 May 2002 with values for both nitrate and organics reaching up to $14 \mu \mathrm{g} / \mathrm{m}^{3}$. Also the sulfate and ammonium mass concentrations during this period markedly exceed the average values measured during the campaign. Backward trajectory calculations performed with the LM1 model of DWD and with the NOAA HYSPLIT model confirmed that the air masses that arrived at the Hohenpeissenberg station between 21 May 2002, 22:00, and 23 May 2002, 20:00, have encountered the polluted Po Valley area in northern Italy within the planetary boundary layer between 18 and $48 \mathrm{~h}$ prior to our measurements. The arrival times of the 


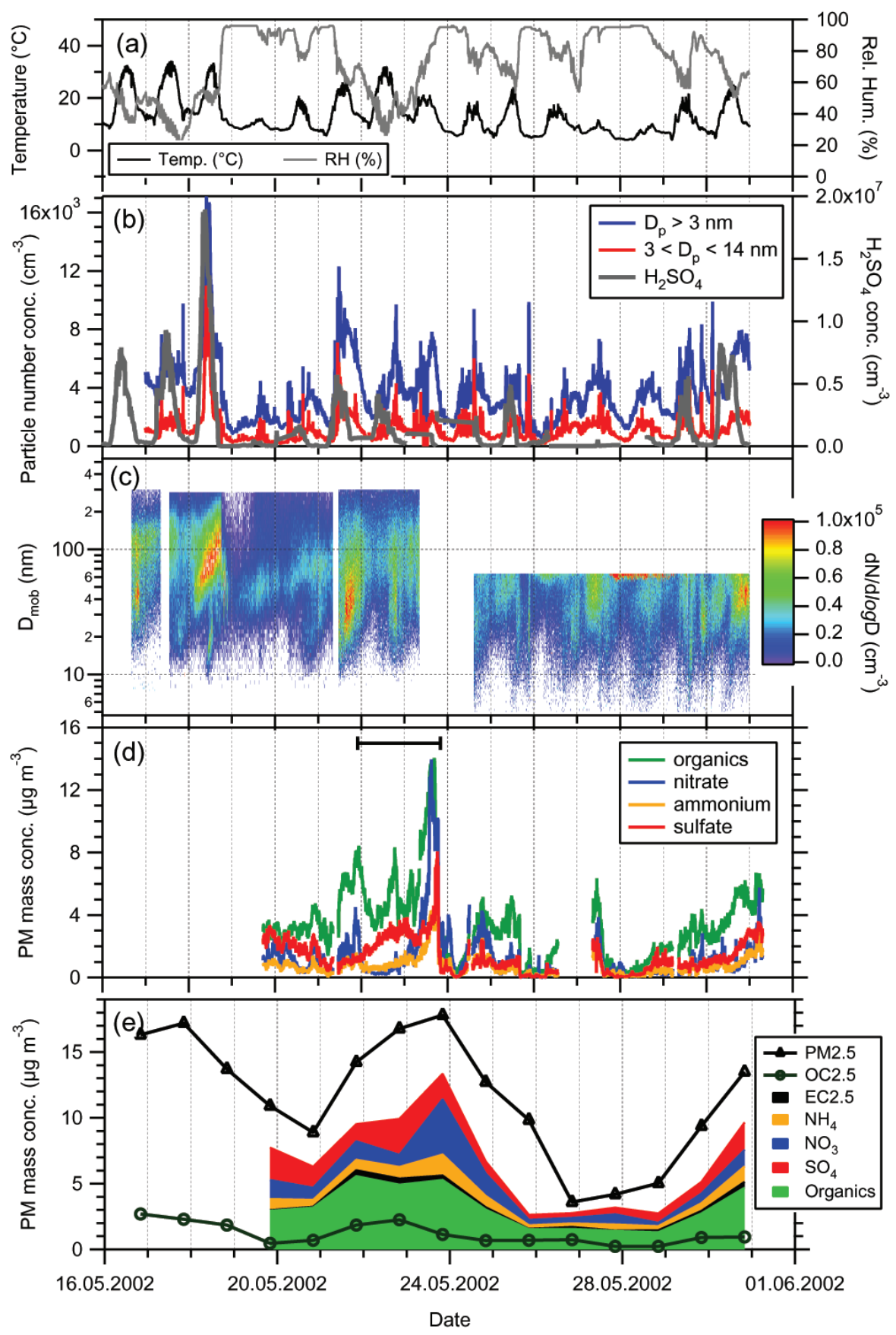

Fig. 1. Time series of the measured quantities during HAZE2002: (a) Temperature and relative humidity; (b) Total ( $>3 \mathrm{~nm}$ ) and ultrafine (3-14 nm) particle number density along with $\mathrm{H}_{2} \mathrm{SO}_{4}$ number concentration. (c) Number size distribution measured with the SMPS; (d) Mass concentrations of ammonium, sulfate, nitrate and organics measured by the Q-AMS; (e) 24-h averaged mass concentrations (stacked: organics, EC2.5, ammonium, nitrate, sulfate), along with OC2.5 and total PM2.5.

trajectories originating from the Po Valley are indicated with the horizontal bar in panel (d) of Fig. 1 .

The correlation between PM1 and the HVS mass concentration (PM2.5) is given in Fig. 2a). To obtain PM1, we added EC2.5 to the sum of the Q-AMS concentrations to ac- count for the fact that the Q-AMS does not detect elemental carbon. The error by adding a PM2.5 quantity to PM1 data is regarded to be negligible, because we do not expect a large fraction of elemental carbon to be found in the size range between 1.0 and $2.5 \mu \mathrm{m}$. The term "PM1" in this paper will 

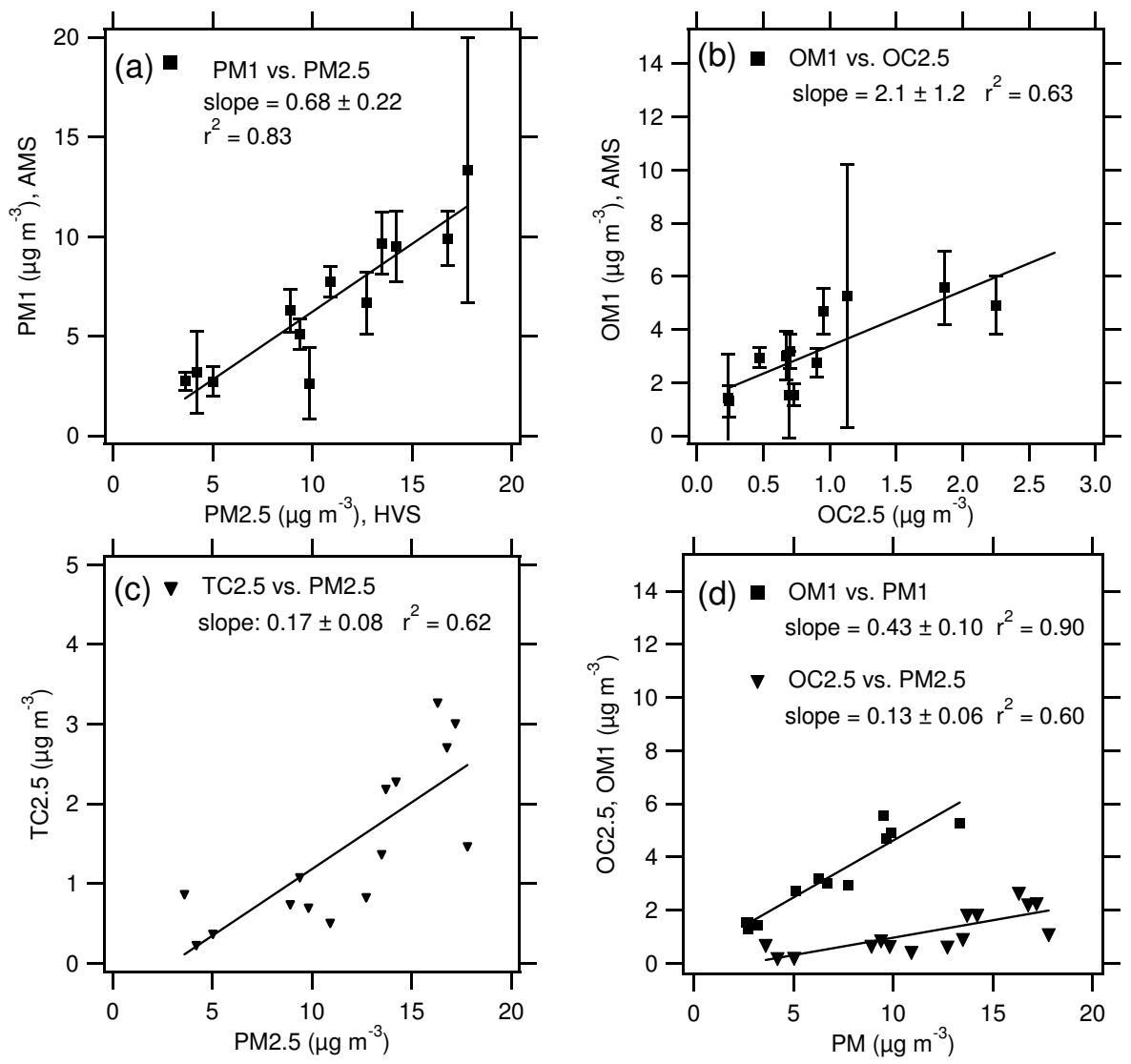

Fig. 2. Correlation between various aerosol parameters measured with the Q-AMS (PM1) and the HVS (PM2.5): (a) PM1 (derived by summing the Q-AMS mass concentrations plus EC2.5 from HVS) vs. total PM2.5 mass concentration from HVS; (b) Total organic mass concentration from Q-AMS (OM1) vs. OC2.5 from HVS (as difference of total carbon (TC) and elemental carbon (EC)). (c) Total carbon (TC2.5) vs. PM2.5 from HVS; (d) OM1 vs. PM1 and OC2.5 vs. PM2.5 (HVS). The error bars represent the standard deviations within the averaging intervals of Q-AMS data to HVS sampling intervals.

therefore refer to "sum Q-AMS" plus EC2.5. The linear regression has a slope of $0.68 \pm 0.22$. The overall ratio of PM1 to PM2.5 was 0.62 . Note that other refractory material like mineral dust is also not measured by the Q-AMS. It further has to be noted that this PM1/PM2.5 ratio is based on the chosen $C E$ factor of 0.5 .

Verification of the chosen $C E$ value relies on the following observations: For the first half of the measurements also a complete size distribution, recorded by an SMPS system $(10-300 \mathrm{~nm})$ and an optical particle counter $(>300 \mathrm{~nm})$ are available. In order to obtain PM1 and PM2.5, respectively, from this data set, we selected a refractive index of 1.450 , converted number distributions into volume distributions assuming spherical particles, integrated the size distributions to the corresponding upper limits, and converted volume to mass using a density of $1.3 \mathrm{~g} \mathrm{~cm}^{-3}$. The values for the refractive index and the density were taken from the comparisons shown in Sect. 3.2. The result shows that the PM2.5 values inferred from both methods do not agree: An average particle density of 2.8 is required to obtain mass closure, a value that is certainly too high to be realistic. However, determination of a mass concentration by a gravimetric method is in general more reliable than converting a number distribution into a mass concentration. Comparing PM1 from SMPS + OPC to PM1 from AMS shows good agreement when a density of 1.3 and a collection efficiency of 0.5 is used, but this would imply that no refractory material other than EC is present.

We can obtain the maximum and minimum value for the collection efficiency of the AMS using the following extreme assumptions:

1. We take PM2.5 from the HVS, subtract the mass between 1 and $2.5 \mu \mathrm{m}$, obtained from the OPC using a density of $1.3 \mathrm{~g} \mathrm{~cm}^{-3}$, subtract EC2.5, and assume that no other refractory material is present. This method yields $C E \approx 0.33$.

2. We take PM1 from SMPS and OPC, use a density of $1.3 \mathrm{~g} \mathrm{~cm}^{-3}$, and assume that $33 \%$ of PM1 is refractory material. Then we arrive at $C E \approx 0.66$. 
Thus, an average $C E$ value of 0.5 seems justified, but has an uncertainty of \pm 0.16 , corresponding to $33 \%$.

Chemical resolved mass concentrations from the HVS are available only for organic carbon (OC2.5), which is calculated by the difference of total carbon (TC2.5) and elemental carbon (EC2.5). Figure 2b shows the correlation between the total organic mass concentration measured with the Q-AMS (= total organic matter, OM1) and OC2.5.

We determined the possible error introduced by comparing OM1 to OC2.5 using the following procedure: As explained above, we estimated the mass in the aerosol phase between 1.0 and $2.5 \mu \mathrm{m}$. The result shows that the size range between 1.0 and $2.5 \mu \mathrm{m}$ contributes only with $(4.53 \pm 1.38) \%$ to the PM2.5 mass concentration (mean value and standard deviation). If we assume a "worst case" scenario, i.e., we assume that the complete aerosol mass between 1.0 and $2.5 \mu \mathrm{m}$ $\left(0.53 \pm 0.23 \mu \mathrm{g} \mathrm{m}^{-3}\right)$ is made up of OM and add this to the OM measured by the AMS, the AMS OM values increase by $(15 \pm 5) \%$. However, this increase is not uniformly distributed over the $\mathrm{OM}$ mass concentration range. As a result, the slope of Fig. 2b does not change significantly. Summarizing, taking into account the possible maximum contribution of OM between 1.0 and $2.5 \mu \mathrm{m}$ does not affect the OM1 to OC2.5 slope. The uncertainty range from the linear regression is \pm 1.2 . Together with the $33 \%$ uncertainy of the collection efficiency this results in a value for the OM1 to OC2.5 slope of 2.1 1.4 .

Although large variations of the total aerosol concentration and composition have been observed during the campaign, OM1 and OC2.5 are well correlated with an $r^{2}$ value of 0.63 . OM/OC ratios for rural locations reported in the literature range between 1.8 and 2.3 (Bae et al., 2006; El-Zanan et al., 2005; Yu et al., 2005; Lim and Turpin, 2002; Turpin and Lim, 2001; Gelencser, 2004) while for urban and polluted continental locations values between 1.2 and 1.6 were reported (Turpin and Lim, 2001; Lim and Turpin, 2002; Gelencer, 2004; Bae et al., 2006; Gilardoni et al., 2007). Thus, our value of $2.1 \pm 1.4$ is in very good agreement with the literature values for rural organic aerosol and indicates that the average organic aerosol measured during HAZE was not substantially influenced by fresh anthropogenic emissions. Compounds dominating fresh anthropogenic emission (e.g., alkanes, alkenes, aromatic hydrocarbons) have low OM/OC ratios in the range of $1.1-1.2$, while oxygenated organic components that are indicative of aged or secondary organic aerosol (e.g., dicarboxylic acids, ketones, aldehydes) have $\mathrm{OM} / \mathrm{OC}$ in the range of 2.3 to 3.8 (Russell, 2003). In our data, underestimation of OM1 in comparison to OC2.5 due to the different upper size cuts would result in an even higher ratio. It must further be stressed that this ratio is directly dependent on the assumed Q-AMS collection efficiency factor for organic particles which was chosen to $C E=0.5$. But since the same conclusion will later be drawn from a Q-AMS internal method (independent on $C E$, see Sect. 3.4.1), the picture is consistent.
Figure $2 \mathrm{c}$ shows the correlation between total carbon (TC2.5) and total particulate matter (PM2.5), Fig. 2d gives the correlations between OC2.5 and PM2.5 as well as between OM1 and PM1. The high correlation between OM1 and PM1 $\left(r^{2}=0.90\right.$ for the diurnal averages and $r^{2}=0.89$ for the AMS time resolution of $10 \mathrm{~min}$ ) indicates that in spite of strongly changing meteorological conditions and absolute concentration levels of particulate matter $\left(3-13 \mu \mathrm{g} \mathrm{m}^{-3}\right.$ PM1), the ratio of non-refractory organics and inorganics of 1:1 was nearly constant.

The non-refractory inorganic components, namely ammonium nitrate and ammonium sulfate, were calculated from the measured $\mathrm{NH}_{4}, \mathrm{NO}_{3}$, and $\mathrm{SO}_{4}$ by assuming that ammonium preferably neutralizes sulfate and adding the remaining ammonium to the nitrate concentration to obtain ammonium nitrate. This results in average values (mean and standard deviations) of (23 \pm 39$) \%$ ammonium nitrate and $(27 \pm 23) \%$ ammonium sulfate, while the remaining $(50 \pm 40) \%$ are organics (OM1). Previously published data by several authors (e.g., Meszaros and Horvath, 1984; Willison et al., 1985; Zhang et al., 2003; Morino et al., 2006) showed that there is a temperature dependency of the partitioning of ammonium nitrate between the gas phase and the solid phase. If the ambient relative humidity $(\mathrm{RH})$ is lower than the deliquescence relative humidity $(\mathrm{DRH})$, ammonium nitrate exists in the solid phase, if $\mathrm{RH}$ is higher than $\mathrm{DRH}, \mathrm{NH}_{4} \mathrm{NO}_{3}$ dissociates to $\mathrm{NH}_{4}^{+}$and $\mathrm{NO}_{3}^{-}$in an aqueous solution. If $\mathrm{NH}_{3}$ and $\mathrm{HNO}_{3}$ can exchange readily between the gas and particle phases, a temperature dependent equilibrium exists between particulate $\mathrm{NH}_{4} \mathrm{NO}_{3}$ and gaseous $\mathrm{NH}_{3}$ and $\mathrm{HNO}_{3}$ (Mozurkewich, 1993). During HAZE2002, ambient temperatures ranged between $32^{\circ} \mathrm{C}$ and $14^{\circ} \mathrm{C}$ (see Fig. 1). Figure 3 shows the ratio of ammonium nitrate mass concentration and the total non-refractory PM1 mass concentration (measured with the Q-AMS) as a function of temperature, as $2 \mathrm{~h}$-mean values, and binned into temperature bins of $2 \mathrm{~K}$ below $298 \mathrm{~K}$. Above $298 \mathrm{~K}$ we used one 4-K bin and one 5-K bin, since less data points were available. The data fall into two regimes: Below a temperature of about $293 \mathrm{~K}$, the ammonium nitrate fraction remains fairly constant (about $25 \%$ ), while above $293 \mathrm{~K}$ the $\mathrm{NH}_{4} \mathrm{NO}_{3}$ fraction decreases and reaches zero at about $303 \mathrm{~K}$. These data illustrate shifting of the equilibrium of $\mathrm{NH}_{4} \mathrm{NO}_{3}$ into the gas phase at temperatures above $293 \mathrm{~K}$. Similar observatons were reported by Zhang et al. (2003) who found an anticorrelation of nitrate with temperature in the temperature range between 292 and $308 \mathrm{~K}$ during the 1999 Atlanta Supersite Experiment.

\subsection{Aerosol size distributions}

Figure 4 gives the chemically resolved size distributions of the four species measured by the Q-AMS as a function of time for the second week of the campaign. During the observed time period, the submicron aerosol mass is concentrated in a size range (vacuum aerodynamic diameter) 
between 200 and $600 \mathrm{~nm}$. In the following we will concentrate on three time periods $\mathrm{A}, \mathrm{B}$, and $\mathrm{C}$ (see Table 1 and Fig. 4) showing a distinct difference in the chemically resolved size distributions: Period A is characterized by high concentrations of all four species, period B by high sulfate and organics but low nitrate and ammonium, while in period $\mathrm{C}$ the aerosol mass concentrations of all four species are markedly lower than before. Figure 5 depicts the size distributions averaged for these three time periods A, B, and C. Size distribution data have additionally been obtained from SMPS and OPC. In order to compare the size distributions obtained with Q-AMS, SMPS, and OPC, the mean density of the aerosol particles was estimated from the chemical composition. Ammonium sulfate and ammonium nitrate were calculated from the measured sulfate and nitrate content. These data are given in Table 1. The vacuum aerodynamic diameter $\left(d_{v a}\right)$ was converted into volume equivalent diameter $d_{v e}$ under the assumption of spherical particles using the equation

$d_{v e}=d_{v a} \cdot \frac{\rho_{0}}{\rho_{p}}$

(Jimenez et al., 2003a), where $\rho_{p}$ is the particle density and $\rho_{0}$ is the density of water. The mobility diameter measured by the SMPS equals the volume equivalent diameter for spherical particles (DeCarlo et al., 2004).

For the optical particle counter PALAS PCS 2010, we performed Mie calculations following the algorithms of (Bohren and Huffmann, 1983), in order to find the refractive index at which the obtained size distributions match best to the AMS size distribution. The PCS 2010 operates with a white light source and the scattered light is detected under $90^{\circ}$ (Umhauer, 1983). It was calibrated with PSL spheres of $800 \mathrm{~nm}$ (refractive index $n=1.588$ ) at the beginning of the campaign. By comparing the total mass distribution of the Q-AMS and the mass distribution obtained by the OPC (using the density inferred from chemical composition), it was found that the data match best for refractive indices of 1.400 and 1.450 , respectively (see Table 1 ). The SMPS size range reaches only up to $65 \mathrm{~nm}$ (due to the use of the Nano-DMA). In this size range the transmission of the aerodynamic lens of the Q-AMS is less than $100 \%$. Additionally, the low mass concentrations observed in period $\mathrm{C}$ leads to larger uncertainties and therefore also to some negative values in the mass size distributions measured by the Q-AMS, which makes comparison between Q-AMS and SMPS difficult, although qualitative agreement is achieved.

In the following we will focus on the wet removal process observed during a precipitation event which occurred between 14:00 and 20:00 on 25 May 2002, with highest rain rates of $>0.1 \mathrm{~L} \mathrm{~m}^{-2} \mathrm{~min}^{-1}$ between 14:00 and 16:00 (lowest panel of Fig. 4). The three time periods A, B, and C shown in Figs. 3 and 4 reflect the wet removal of aerosol particles during the precipitation event on 25 May 2002. The CO data (lowest panel of Fig. 4) show that no air mass change oc-

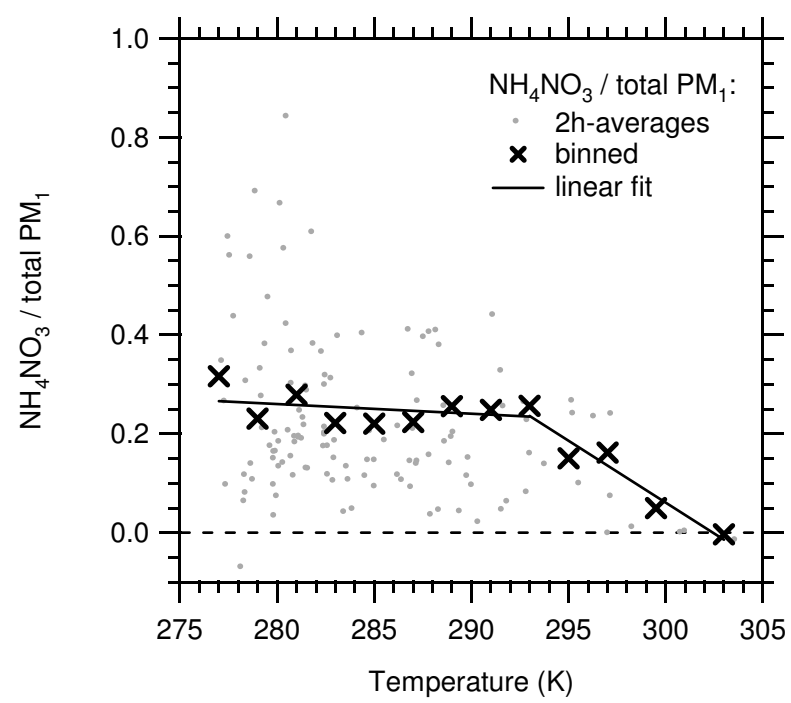

Fig. 3. Measured ratio of $\mathrm{NH}_{4} \mathrm{NO}_{3}$ mass concentration to total aerosol mass concentration as a function of temperature, binned into temperature intervals. The dots indicate the two hour averages. The solid lines represent linear fits to the temperature ranges below and above $293 \mathrm{~K}$.

curred during the precipitation event and therefore the decrease of the mass concentrations (Table 1) is only due to wet removal. The mass concentrations before and after the precipitation event suggest different wet removal efficiency for the different species: Ammonium sulfate is removed by a factor of 12 , ammonium nitrate by a factor of 19 , organics by a factor of 8 .

This can be seen as an indication for partial external mixture of the aerosol particles, since in a complete internal mixture all species would be removed to the same degree. Small organic particles appear to be less efficiently removed, as shown by panel (c): After the precipitation event, an aerosol mode around $60-80 \mathrm{~nm}$ is present which is dominated by organic compounds.

\subsection{The organic fraction of the aerosol particles}

\subsubsection{Oxygenated organic aerosol (OOA) and hydrocarbon-like organic aerosol (HOA)}

The correlation between the organic mass concentration measured by the Q-AMS (OM1) and OC2.5 measured by the HVS (Fig. 2b) has already been discussed (Sect. 3.1). In order to further investigate the formation processes of organic aerosol particles, the multicomponent HOA/OOA analysis (MCA, Zhang et al., 2005a, c, 2007) was used.

This analysis yielded 3 major components: a hydrocarbonlike organic aerosol component (HOA) and two oxygenated organic aerosol components (OOA1 and OOA2). HOA contributed $(20 \pm 17) \%$ to the total organics mass, OOA1 $(18 \pm 12) \%$ and OOA2 $(62 \pm 19) \%$, respectively (arithmetic means and standard deviations). The components are 
Table 1. Composition, mean particle density $\rho_{\text {mean }}$ and inferred refractive index $n$ of the aerosol particles for the three time periods (A, B, and C) indicated in Fig. 4.

\begin{tabular}{lllllll}
\hline & $\begin{array}{l}\text { Date \& } \\
\text { Time }\end{array}$ & $\begin{array}{l}\left(\mathrm{NH}_{4}\right)_{2} \mathrm{SO}_{4} \\
\left(\mu \mathrm{g} \mathrm{m}^{-3}\right)\end{array}$ & $\begin{array}{l}\mathrm{NH}_{4} \mathrm{NO}_{3} \\
\left(\mu \mathrm{g} \mathrm{m}^{-3}\right)\end{array}$ & $\begin{array}{l}\text { Organics } \\
\left(\mu \mathrm{g} \mathrm{m}^{-3}\right)\end{array}$ & $\begin{array}{l}\rho_{\text {mean }} \\
\left(\mathrm{g} \mathrm{cm}^{-3}\right)\end{array}$ & $n$ \\
\hline $\mathrm{A}$ & $\begin{array}{l}\text { 24 May 2002, 13:48:00- } \\
\text { 25 May 2002, 00:29:56 }\end{array}$ & 1.50 & 3.22 & 3.55 & 1.32 & 1.450 \\
$\mathrm{~B} \quad \begin{array}{l}\text { 25 May 2002, 03:05:55- } \\
\text { 25 May 2002, 15:47:47 }\end{array}$ & & 0.90 & 3.42 & 1.19 & 1.400 \\
$\mathrm{C} \quad \begin{array}{l}\text { 25 May 2002, 16:47:47- } \\
\text { 26 May 2002, 05:59:40 }\end{array}$ & 0.12 & 0.17 & 0.42 & 1.22 & 1.450 \\
\hline
\end{tabular}

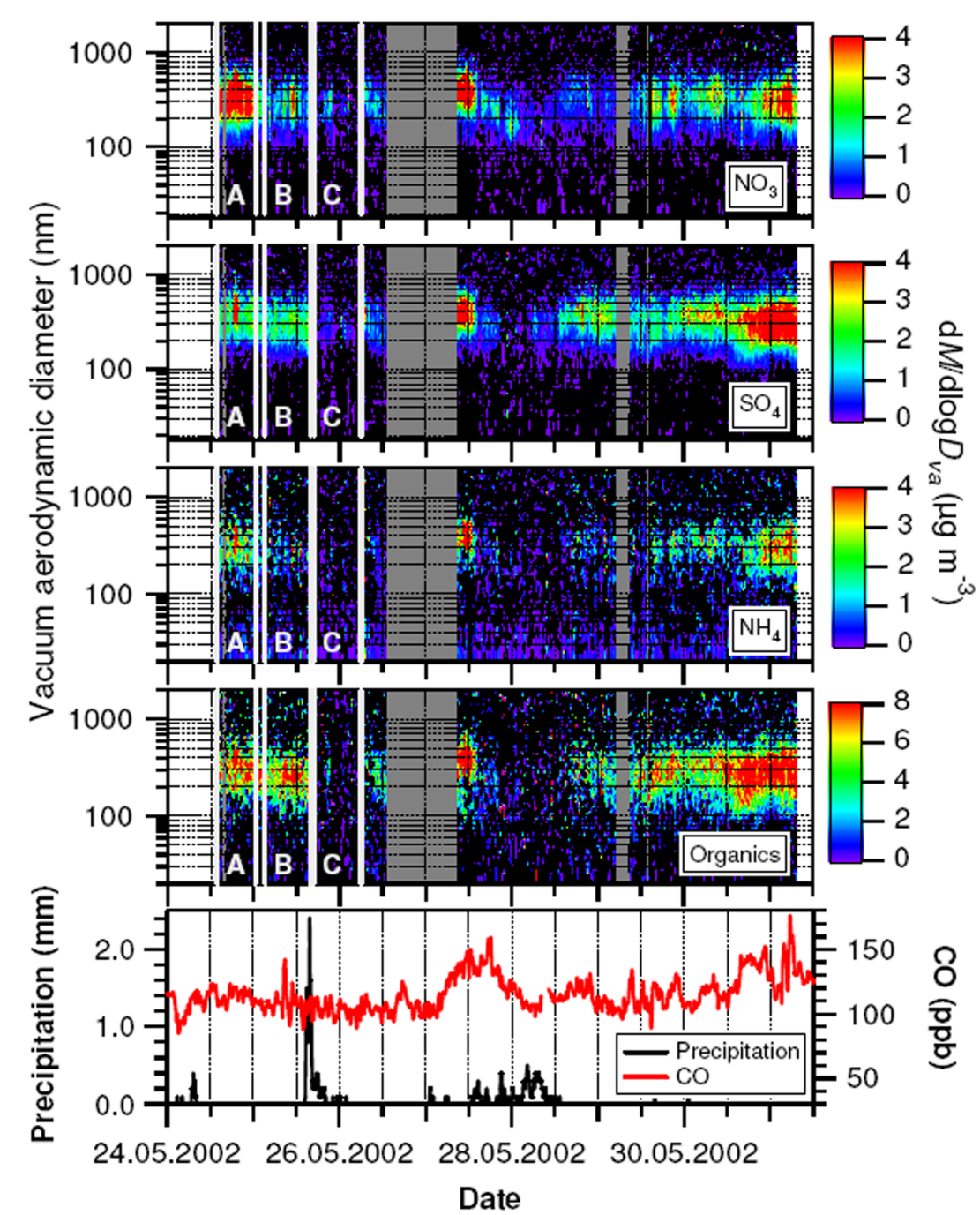

Fig. 4. Size distribution of the individual aerosol species measured with the Q-AMS during the second week of the campaign, along with precipitation and $\mathrm{CO}$ concentration.

displayed in Fig. 6, along with previously recorded mass spectra that resemble the multicomponent analysis results: Panel (a) and (b) compare the HOA component with a mass spectrum from diesel engine exhaust particles measured on a engine test dynamometer (Schneider et al., 2006). Both mass spectra are dominated by the ion series $m / z, 27,29,41,43$, $55,57,69,71,83,85 \ldots$, as has been reported previously for hydrocarbon-like organic aerosol (HOA) from fossil fuel 

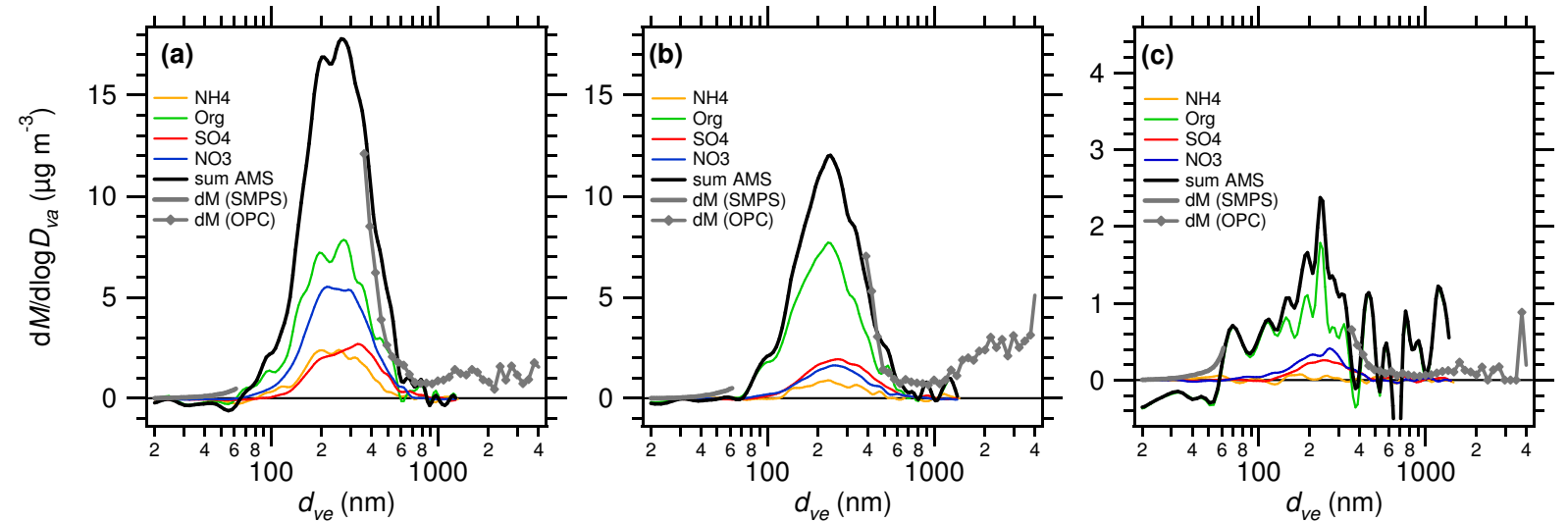

Fig. 5. Mass size distributions measured with the Q-AMS, SMPS and OPC for the three time periods indicated in Fig. 4.

combustion sources (Canagaratna et al., 2004; McLafferty and Turecek, 1992; Zhang et al., 2005a, c, 2006).

Panel (c) and (d) compare the component OOA1 with a a mass spectrum of free tropospheric aerosol sampled at the High Alpine Research Station Jungfraujoch during the CLACE-3 project (Walter et al., 2007 ${ }^{1}$ ). In aged organic aerosol (as encountered in the free troposphere) $\mathrm{m} / \mathrm{z}$ $44\left(\mathrm{CO}_{2}^{+}\right)$dominates, since the $\mathrm{CO}_{2}^{+}$has been found to be strongly associated with oxygenated organic compounds in aerosols (Alfarra et al., 2004; Zhang et al., 2005a), while in fresh anthropogenic emissions (as in diesel exhaust) $\mathrm{m} / \mathrm{z} 44$ contributes only to a small degree, compared to other peaks. Similar to $m / z 44, m / z 18\left(\mathrm{H}_{2} \mathrm{O}^{+}\right)$is also a fragmentation product of the vaporization of oxidized aerosol compounds that was found to be approximately equal in size as $m / z 44$ (Alfarra et al., 2004) and is therefore set equal to $m / z 44$ by the analysis software (Allan et al., 2004b).

Panels (e) and (f) compare the component OOA2 (which dominated the organic fraction) with a mass spectrum from secondary organic aerosol (SOA) particles from $\beta$-pinene oxidation. In both mass spectra, the mass fragment $m / z 43$ $\left(\mathrm{C}_{3} \mathrm{H}_{7}^{+}\right.$or $\left.\mathrm{C}_{2} \mathrm{H}_{3} \mathrm{O}^{+}\right)$is the highest peak, followed by $m / z 44$ (and $m / z$ 18). Further prominent peaks are $m / z 41\left(\mathrm{C}_{3} \mathrm{H}_{5}^{+}\right.$ or $\left.\mathrm{C}_{2} \mathrm{HO}^{+}\right), m / z 29\left(\mathrm{C}_{2} \mathrm{H}_{5}^{+}\right.$or $\left.\mathrm{CHO}^{+}\right), m / z 27\left(\mathrm{C}_{2} \mathrm{H}_{3}^{+}\right)$, and $m / z 55\left(\mathrm{C}_{4} \mathrm{H}_{7}^{+}\right.$or $\left.\mathrm{C}_{3} \mathrm{H}_{3} \mathrm{O}^{+}\right)$. Although both mass spectra (e) and (f) are not identical, the patterns are quite similar, indicating that the dominating component (OOA2) is influenced by secondary organic aerosol formation.

Similar mass spectrometric patterns for two different types of oxygenated organic aerosol were found by positive matrix factorization (PMF) from aerosol sampled at Zurich,

\footnotetext{
${ }^{1}$ Walter, S., S., Schneider, J., Hock, B. N., Curtius, J., Borrmann, S., Mertes, S., Weingartner, E., Verheggen, B., Cozic J., Baltensperger, U., Allan, J. D., Crosier, J., Bower, K., and Coe, H.: On the chemical composition of ice nuclei: Results from the 3rd and 4th Cloud and Aerosol Characterization Experiment (CLACE), Atmos. Chem. Phys. Discuss., in preparation, 2008.
}

Switzerland (Lanz et al., 2007). The source profile "OOA type I" displayed in Fig. 3 in Lanz et al. corresponds well to our aged organic aerosol "OOA1". The second OOA component ("OOA type II") in Lanz et al. is somewhat different from our "OOA2" component: We find a large contribution also of $m / z 44$ in this mass spectrum, while in "OOA type II" from Lanz et al., $m / z 44$ is completely missing.

Panels (g) and (h) show two mass spectra recorded during HAZE: The mass spectrum (g) was averaged over a time period when the air masses were arriving from the West (24 May 2002, 00:00-24 May 2002, 12:00), while the mass spectrum (h) was averaged for a time period when air masses arrived from the Po Valley, Italy, and the organic mass concentrations were highest (21 May 2002, 22:00-23 May 2002, 20:00, as indicated in Fig. 1). These mass spectra that were chosen only on the basis of trajectory analysis show certain differences that need to be discussed. The ratios $m / z 29$ to $m / z 27$ as well at the ratios $m / z 44$ to $m / z 43$ and $m / z 57$ to $m / z 55$ are significantly higher in spectrum $(\mathrm{g})$ than in spectrum (h). The finding that the ratio $m / z 44$ to $m / z 43$ is higher indicates that the organic aerosol components in these air masses have experienced more photochemical aging than the aerosol particles arriving with the air masses from the polluted Po Valley. Aerosol particles emitted by industrial pollution in the Po Valley region have spent approximately two days in the atmosphere before reaching the measurement station. Mass spectrum (h) can therefore be regarded as an example for photochemical conversion of anthropogenic emitted aerosol particles. The high ratio of $\mathrm{m} / \mathrm{z}$ 29 to $m / z 27$ (the highest of all spectra displayed in Fig. 6) might indicate influence of biomass burning (Alfarra et al., 2007) but $m / z 29$ is not unique to this source and therefore might have other explanations. Biomass burning does not appear to be a likely source since no large contributions of residential wood burning are expected in May in southern Germany. Furthermore, the most indicative marker for biomass burning, $m / z 60$ (Schneider et al., 2006; Alfarra et al, 2007) is not found to be elevated in mass spectrum $(\mathrm{g})$. 

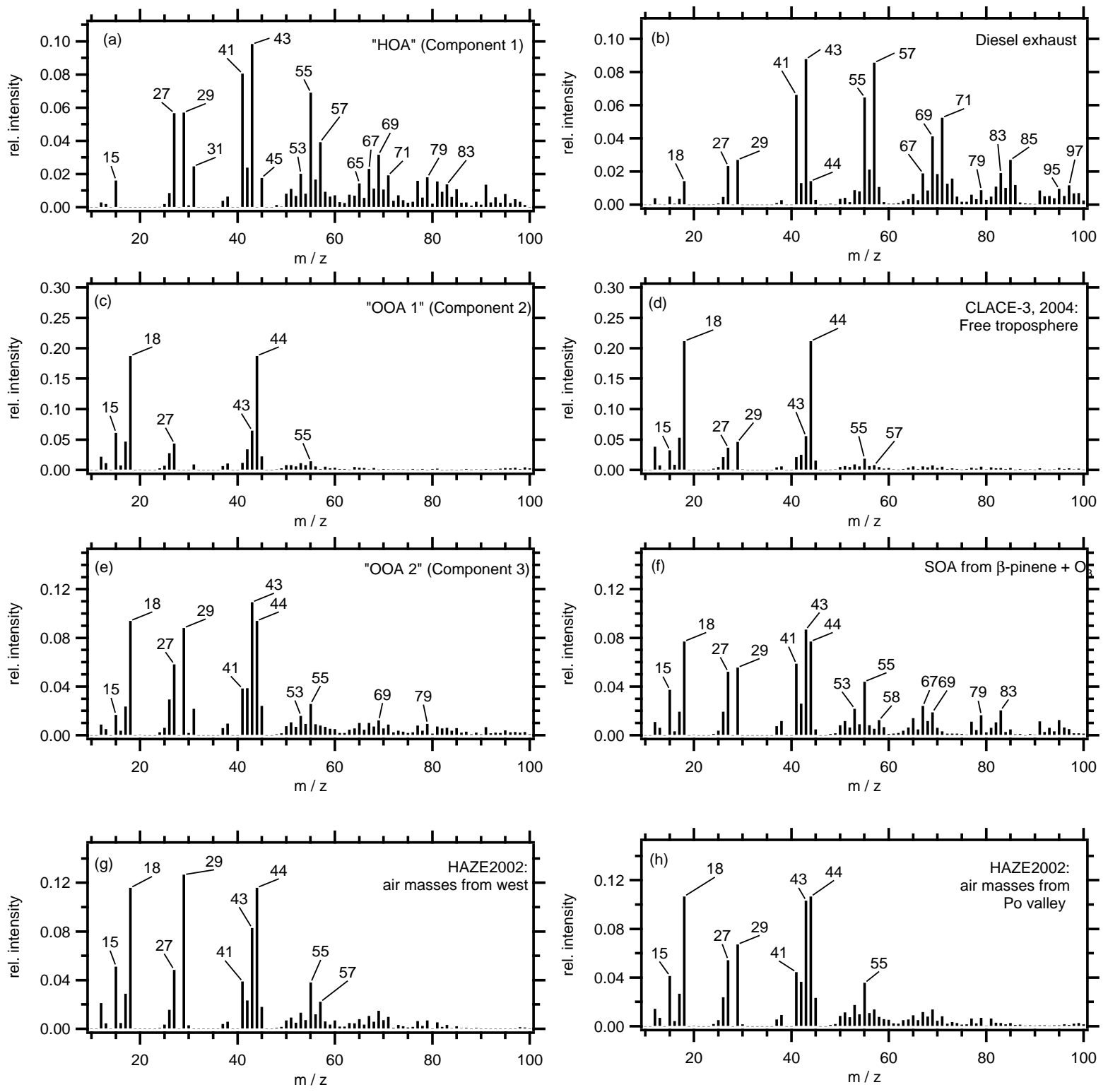

Fig. 6. Comparison of the MCA results with reference mass spectra: (a) HOA (component 1) (b) Diesel exhaust measured at an engine test facility (Schneider et al., 2006); (c) OOA1 (component 2); (d) Free tropospheric aerosol measured at the Jungfraujoch station during CLACE-3 (Walter et al., 2007 ${ }^{1}$ ); (e) OOA2 (component 3); (f) SOA from $\beta$-pinene oxidation; (g) HAZE2002, averaged over the time period when the air masses arrived from westerly direction; (h) HAZE2002, averaged over the time period when the air masses arrived from the Po Valley

Figure 7 displays the diurnal pattern of the three components. The diurnal cycle is similar for all three components, with higher values between 09:00 and 21:00 and lower values during nighttime between 21:00 and 09:00. The relative contribution of the three individual types to the total organic mass is nearly constant during the diurnal cycle. The maximum during daylight hours reflects the photochemical production of aerosol of type OOA2, while the contribution of the aged organics fraction (OOA1) and the fossil fuel burning related HOA play only a minor role in the diurnal cy- cle. A further indication for the fact that direct emissions of HOA (e.g. traffic exhaust) play only a minor role in the diurnal cycle is the absence of the morning traffic peak between 07:00 and 09:00. This morning traffic peak has been observed previously in urban measurements (Drewnick et al., 2004; Zhang et al., 2005b) where primary anthropogenic HOA emissions are more important.

Figure 8 shows the correlation between the mass concentration of $\mathrm{m} / \mathrm{z} 44$ and the total organic mass concentration for the measurements during HAZE2002. The data points 


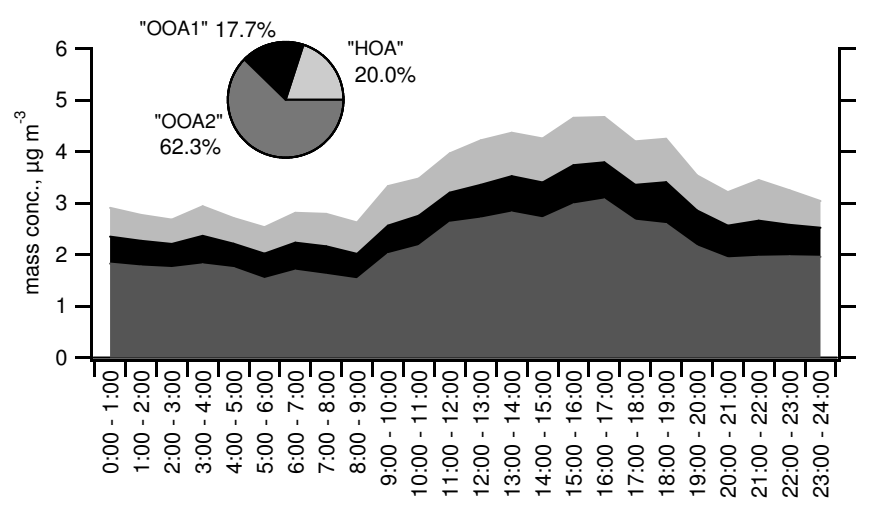

Fig. 7. Diurnal patterns averaged over the whole measurement period of HOA, OOA1 and OOA2 obtained from the multicomponent analysis.

reveal an average regression slope of 0.09 for the HAZE2002 data. For comparison, the slopes from two other data sets are plotted: Data obtained from diesel exhaust particles that contain mainly hydrocarbon-like organic compounds (Panel b in Fig. 6) yield a slope of 0.05 , while data measured in the free troposphere (Panel d in Fig. 6) are highly oxidized and reveal a slope of 0.20 . This implies that the ratio of $m / z 44$ to total organics measured with the Q-AMS can be used as an approximation for the degree of oxidation of organic aerosol compounds for ambient aerosol data. This method has already been applied by Takegawa et al. (2005) for Tokyo city, who inferred a low degree of oxidation for a ratio of $m / z 44$ to total organics below 0.04 and a highly oxidized aerosol for a ratio above 0.08 . Following this classification, the average aerosol observed during HAZE2002 was "highly" oxidized. However, it must be stressed that this method can only be applied in field data that are not influenced be fresh biomass burning emissions since biomass burning particles are likely to deviate from this behavior (Schneider et al., 2006). Mass spectrometric markers for biomass burning aerosol are $\mathrm{m} / \mathrm{z}$ 60, $m / z$ 73, and $m / z 137$ (Schneider et al., 2006; Alfarra et al., 2007). Although a small signature of $m / z 60$ is observed in the HAZE mass spectra, and $m / z 60$ was found to be weakly correlated with CO during HAZE2002 $\left(r^{2}=0.38\right)$, the MCA results do not indicate an biomass burning aerosol component. Thus we can conclude that the measurement site was not significantly influenced by biomass burning. This finding is not unexpected, because the domestic heating season is over in Southern Germany during May and June, and no forest fires were noticed or reported in that area during our measurements. Also given in Fig. 8 is the slope of the part of the data when the air masses arrived from the Po Valley, Italy, and the organic mass concentrations were highest (21 May 2002, 22:00-23 May 2002, 20:00, labelled “polluted"). For these data, the slope is slightly lower (0.08), indicating a less oxidized aerosol and a higher influence of anthropogenic emissions.

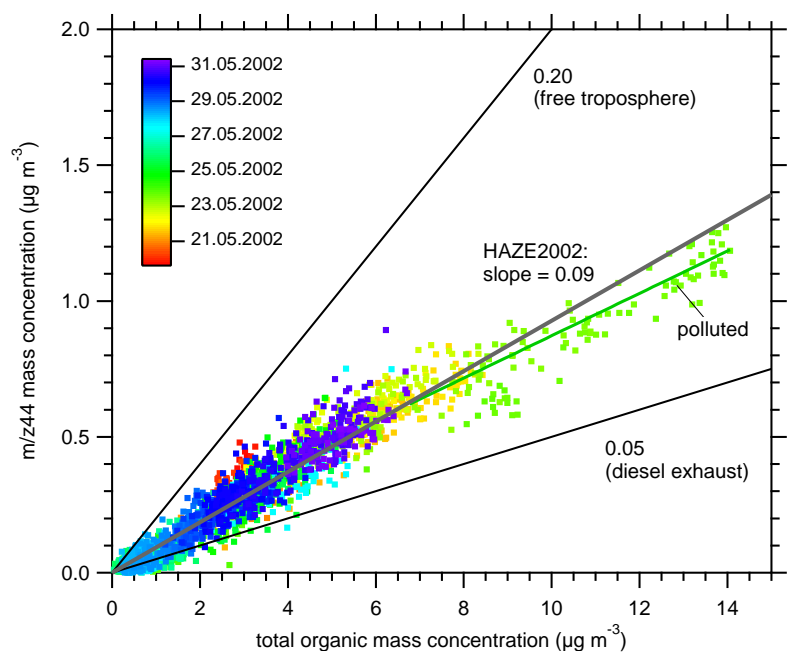

Fig. 8. Correlation between the mass concentrations of $\mathrm{m} / \mathrm{z} 44$ and total organics along with ratios measured in the free troposphere (Walter et al., 2008 ${ }^{1}$ ) and in diesel exhaust (Schneider et al., 2006). The label "polluted" denotes only the data between 21 May 2002, 22:00 and 23 May 2002, 20:00, when the air masses originated from the Po valley.

\subsubsection{Polycyclic aromatic hydrocarbons (PAHs) and pro- teins}

Figure 9 shows the measured concentrations of polycyclic aromatic hydrocarbons (PAHs) and of proteins. PAHs are characteristic trace components of pyrogenic aerosols from fossil fuel combustion and biomass burning, whereas proteins are characteristic main components of primary biological particles. The PAH concentrations were mostly in the range of $0.2-0.4 \mathrm{ng} \mathrm{m}^{-3}$ and exhibited only little variability, except for an increase towards the end of the measurement period which coincides with lower temperatures and may be attributable to local heating emissions. Even the elevated concentrations observed at the end of the campaign $\left(\sim 0.6 \mathrm{ng} \mathrm{m}^{-3}\right)$, however, were much lower than the concentration levels typically observed in the nearest metropolitan area (1-5 $\mathrm{ng} \mathrm{m}^{-3}$, city of Munich, Schauer et al., 2004, 2003a) and in polluted urban areas around the world (20$110 \mathrm{ng} \mathrm{m}^{-3}$ in Mexico city, 2003; Marr et al., 2006; up to $670 \mathrm{ng} \mathrm{m}^{-3}$ in Delhi, 2002/2003, Sharma et al., 2007). The low PAH concentrations $\left(<1 \mathrm{ng} \mathrm{m}^{-3}\right)$ are fully consistent with the low EC concentrations $\left(<1 \mu \mathrm{g} \mathrm{m}^{-3}\right.$, Fig. 1) observed during HAZE2002; the mass fractions of PAH in diesel soot and the ratio of PAH to EC in atmospheric aerosol samples recently determined with the same analytical techniques were also on the order of $10^{-3}$ to $10^{-4}$ (Schauer et al., 2004, 2003a). Both the PAH and EC measurement results indicate a low contribution of soot and other combustion emissions to the rural aerosols sampled during HAZE2002.

The measured protein concentrations varied in the range of $0.1-0.6 \mu \mathrm{g} \mathrm{m}^{-3}$ and followed essentially the same temporal 


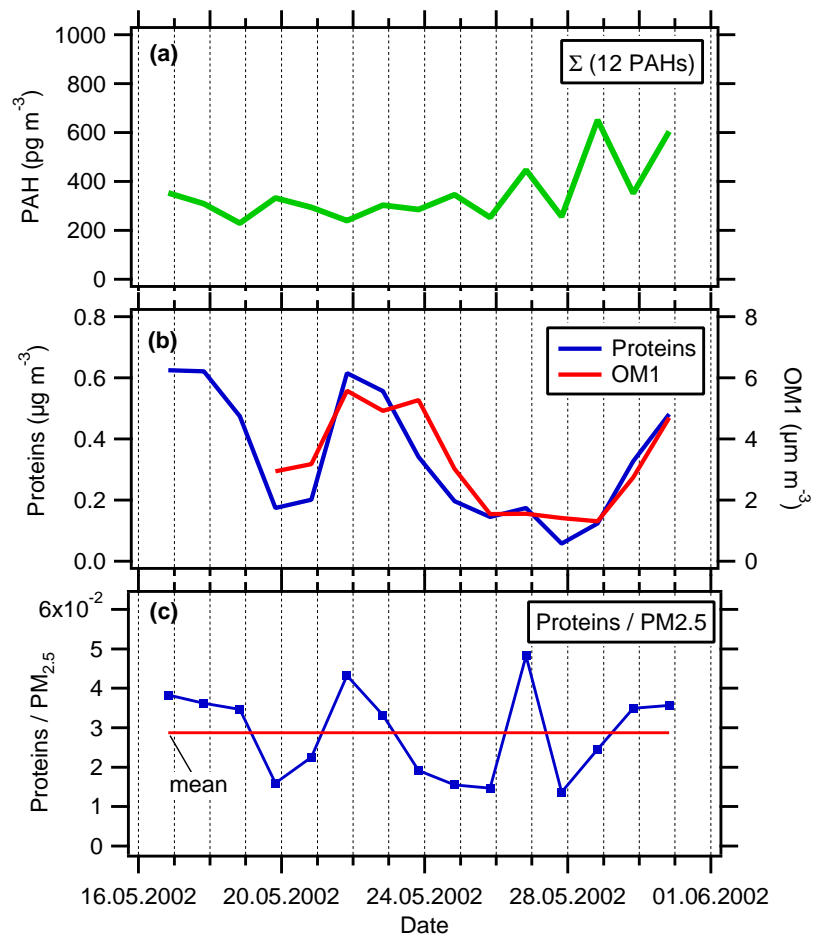

Fig. 9. PAHs und Proteins in PM2.5: (a) Sum of 12 PAHs; (b) Proteins (left scale) along with OM1 (right scale); (c) Ratio of proteins to PM2.5 (mean: 0.029 \pm 0.011 ).

pattern as the concentrations of PM2.5 and OM1, with pronounced minima on 20-21 and 26-29 May. The ratios of proteins to OM1 and PM2.5 were fairly constant at $\sim 8 \%$ and $\sim 3 \%$, respectively, indicating a substantial contribution of primary biogenic particles to the sampled rural aerosol. The relative abundance of proteins in biomass is typically on the order of $\sim 10 \%$, suggesting that $\sim 30 \%$ of the rural PM2.5 sampled during HAZE2002 were of primary biological origin. This first-order estimate is subject to high uncertainties with regard to the characteristic relative abundance of proteins in primary biogenic aerosol particles $(\sim 1 \%$ for wood, $\sim 10 \%$ for leaves, up to $\sim 50 \%$ for microorganisms; GCEP, 2005; Banner et al., 1979; Briza et al., 1988; Zubkov et al., 1999) and potential interferences of humic or humic-like substances with the determination of proteins (Fehrenbach, 2006; Franze, 2004; Graber and Rudich, 2006; Ivleva et al., 2007). Thus, further chemical and biological speciation will be required to corroborate these findings. Nevertheless, they are in agreement with other recent studies indicating high abundances of primary biological particles in atmospheric aerosols (Zhang and Anastasio, 2003; Mikhailov et al., 2004; Jaenicke, 2005; Pöschl, 2005; Despres et al., 2007; Elbert et al., 2007, and references therein). The identification of mass spectrometric markers for primary biological materials appears desirable in order to quantify primary organic aerosol components with the AMS.

\subsubsection{Dicarboxylic acids and monoterpenes}

On 22 May 2002 and 23 May 2002, filter samples were taken with a time resolution of $3 \mathrm{~h}$ during the day (08:00 to 20:00) and $12 \mathrm{~h}$ during the night (20:00 to 08:00). These samples were analyzed for dicarboxylic acids originating from the oxidation of monoterpenes. At the same time gas-phase concentrations of several monoterpenes ( $\alpha$-pinene, $\beta$-pinene, 3 carene and limonene) were measured online/in-situ. These data are depicted in Fig. 10, along with the aerosol mass concentrations measured by the Q-AMS as well as $\mathrm{O}_{3}, \mathrm{NO}_{\mathrm{x}}$ and $\mathrm{OH}$ gas-phase concentrations.

The gas-phase monoterpene concentrations show a sharp decrease during the night between 22 May 2002, 22:30, and 23 May 2002, 04:30. This time period is shaded grey in all four panels. Sabinic and ketolimonic acid also show a minimum during this period. The total organic aerosol as measured by the AMS does not show this minimum. We explain this sharp nighttime decrease of the monoterpenes by the meteorological situation at Hohenpeissenberg (Fig. 11): the measurement station is located on the top of a small mountain that rises about $300 \mathrm{~m}$ above the surrounding area. During the night a stable layer is formed in the lower troposphere due to cooling of the ground. Therefore vertical mixing is very low and the station on top of Hohenpeissenberg is isolated from the emission sources (e.g., monoterpene emitting trees) on the ground. Above this stable inversion layer, wind speeds are higher and air masses are transported horizontally. Consequently the night samples are not affected by local emissions around the sampling station but represent long-range transport of air masses. Any monoterpenes that might have been present in these air masses have already reacted with the remaining ozone. Gas-phase concentrations of ozone and nitrogen oxides were still present at levels comparable to those during the day (ozone remained constant at around $60 \mathrm{ppb}, \mathrm{NO}_{\mathrm{x}}$ ranged between 1.2 and $2.0 \mathrm{ppb}$ ). The same is true for the longer-lived aerosol species such as ammonium sulfate, ammonium nitrate, and for the concentrations of pinic and pinonic acid. The decrease of ketolimonic and sabinic acid during the night is consistent with a decrease in total organics from AMS. It might be due to lower biogenic impact and lower emissions of the corresponding precursor monoterpenes (limonene and sabinene (Warnke et al., 2006)) in the source area of the "aged" air mass. The atmospheric lifetimes of the dicarboxylic acids originating from terpene oxidation should be comparable. These compounds are assumed to be relatively stable and are removed from the atmosphere primarily by dry and wet deposition which should be very similar for the different compounds. Using the measured $\alpha$-pinene and ozone concentrations, and yields determined in laboratory experiments, one would expect substantially higher cumulative production than observed in the aerosol. However, little is known about the decay of these compounds in the particulate phase, which may be the reason 

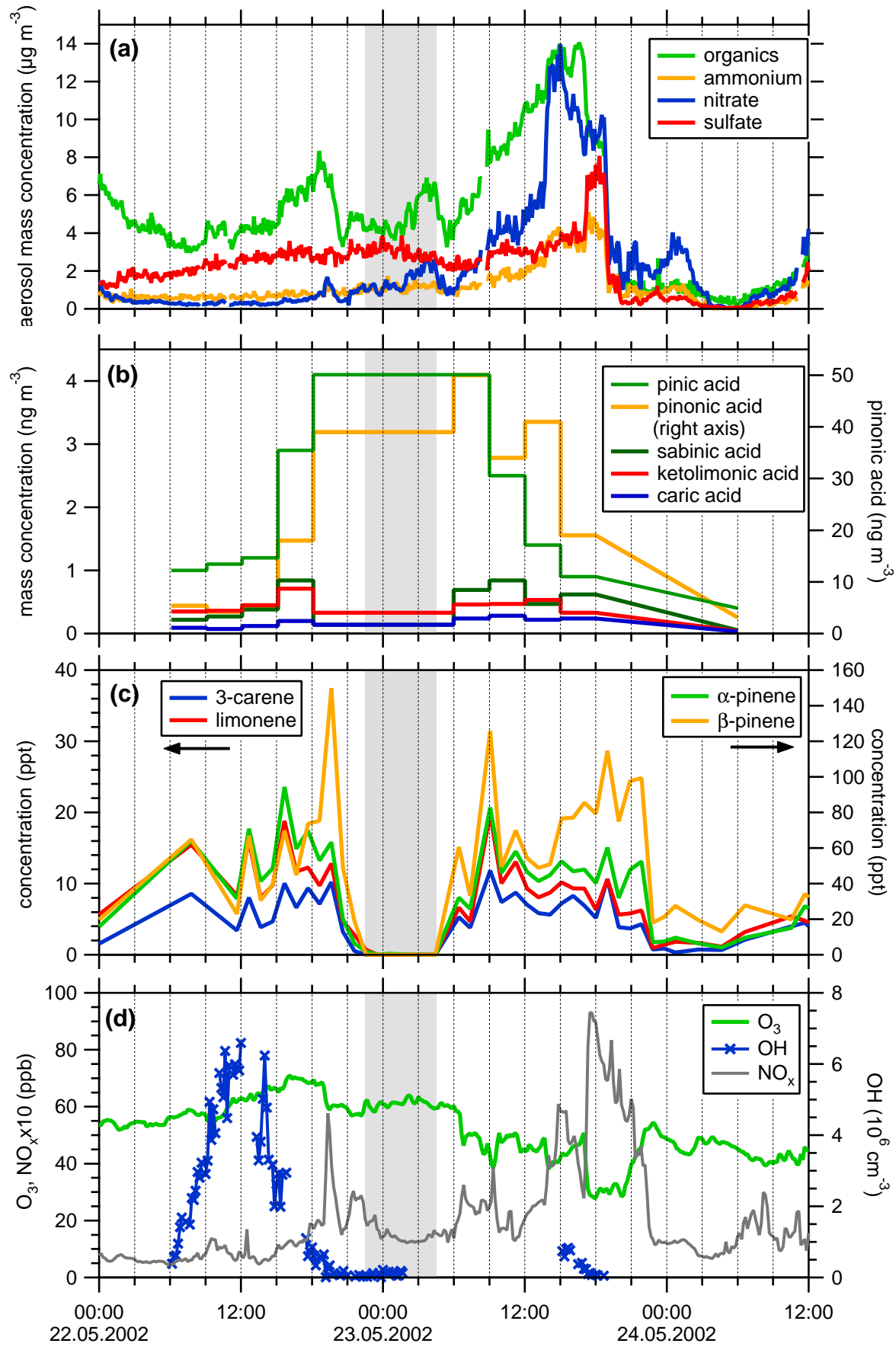

Date and Time

Fig. 10. Expanded time series 22 May to 24 May: (a) Non-refractory PM1 compounds (Q-AMS); (b) dicarboxylic acids; (c) gas-phase monoterpenes; (d) $\mathrm{O}_{3}, \mathrm{NO}_{\mathrm{x}}$ (multiplied by 10), and $\mathrm{OH}$. Grey shading: time period where monoterpenes decrease to zero.

for the different behavior of the caboxylic acids displayed in Fig. 10.

\subsection{New particle formation and growth}

An additional objective of the HAZE2002 project was the investigation of new particle formation or nucleation events. During a previous long-term study, new particle formation events have been observed regularly on $18 \%$ of all days at 
Day

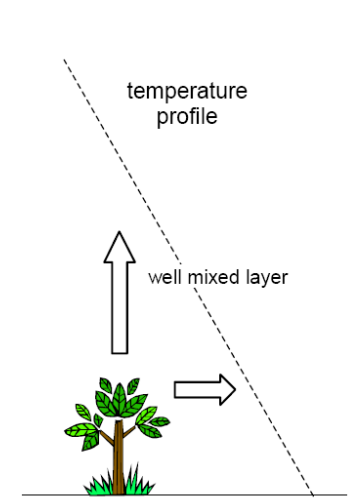

Night

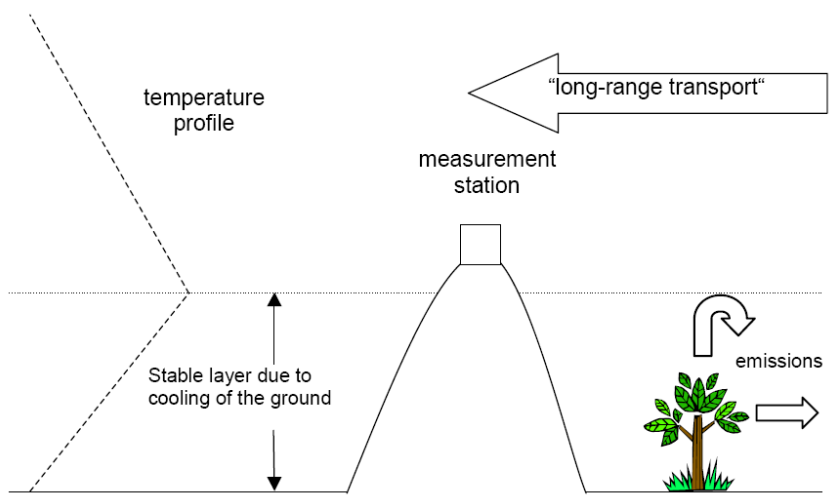

Fig. 11. Meteorological situation at the Hohenpeissenberg.

Hohenpeissenberg (Birmili et al., 2003). Here, we used the particle number concentration between 3 and $14 \mathrm{~nm}$ to identify new particle formation events. These data, given in panel (b) of Fig. 1, reveal that new particle formation occurred almost regularly every afternoon, with the strongest observed nucleation and growth events on 18 May 2002 and 21 May 2002. These two events will be analyzed in more detail in the following.

Figures 12 and 13 show the parameters relevant to nucleation and growth, measured on 18 May 2002 and on 21 May 2002 , respectively. Panels (a) show the time series of number size distribution, measured with the SMPS in a size range between 7 and $300 \mathrm{~nm}$, Panels (b) show the particle concentrations in different size ranges: The total particle concentration $N_{\text {tot }}$ (all particles with diameter $>3 \mathrm{~nm}$ ), and the ultrafine particle concentration $N_{3-14}$ (size range 3-14 nm). On 18 May 2002, the background concentration of particles in a diameter range between 30 and $100 \mathrm{~nm}$ before the onset of nucleation is markedly higher than on 21 May. On both days, newly formed particles are detected in the SMPS system around 11:30. The growth of the particles in the course of the afternoon is only observed on 21 May. The particles grow in diameter from $25 \mathrm{~nm}$ at 11:30 until the modal diameter reaches $50 \mathrm{~nm}$ around 20:00 and remains stable after sunset. The corresponding particle growth rate between 11:30 and 20:00 is $3 \mathrm{~nm} \mathrm{~h}^{-1}$. On 18 May the SMPS did not show the peak detected by the CPCs around 09:30 (Panel b), indicating that these particles had diameters below the lower cut-off size of the SMPS $(7 \mathrm{~nm})$. Assuming particles with diameters smaller than $7 \mathrm{~nm}$ at 09:30 and particle growth to $20 \mathrm{~nm}$ at 13:00, this corresponds to growth rates of about $4 \mathrm{~nm} \mathrm{~h}^{-1}$, a value that is similar to the growth rate of $3 \mathrm{~nm}$ $\mathrm{h}^{-1}$ observed on 21 May. Both values agree well with previous findings by Birmili et al. (2003) who found average growth rates of $2.6 \mathrm{~nm} \mathrm{~h}^{-1}$ at Hohenpeissenberg. The ultrafine particle number concentration on 18 May increases from $1780 \mathrm{~cm}^{-3}$ at $07: 44$ to a maximum value of $10990 \mathrm{~cm}^{-3}$ at
09:55, while on 21 May, $N_{3-14}$ increases from $340 \mathrm{~cm}^{-3}$ at 07:53 to $7100 \mathrm{~cm}^{-3}$ at 10:55.

Panels (c) of Figs. 12 and 13 show the $\mathrm{H}_{2} \mathrm{SO}_{4}$ and $\mathrm{OH}$ concentrations on both days, as measured with selected ion chemical ionization mass spectrometry (SI/CIMS) (Berresheim et al., 2000). On 18 May, a maximum $\mathrm{H}_{2} \mathrm{SO}_{4}$ concentration of $1.9 \times 10^{7} \mathrm{~cm}^{-3}$ is reached, on $21 / 05, \mathrm{H}_{2} \mathrm{SO}_{4}$ reached up to $6 \times 10^{6} \mathrm{~cm}^{-3}$. As shown in Panels (d), the daytime hours featured intense solar radiation of up to 6 and $6.6 \mathrm{~J} \mathrm{~m}^{2}$, temperatures up to $34^{\circ} \mathrm{C}$ and $25^{\circ} \mathrm{C}$, and relative humidities of 50 and $70 \%$, respectively. As additional information, the aerosol mass concentrations for organics, nitrate, sulfate, and ammonium measured on 21 May are displayed in Panel (e) of Fig. 13.

Numerous observations of nucleation rates and $\mathrm{H}_{2} \mathrm{SO}_{4}$ vapor concentration suggest the involvement of $\mathrm{H}_{2} \mathrm{SO}_{4}$ in atmospheric nucleation (e.g., Kulmala et al., 2004). Furthermore, it is known that that under the presence of gas-phase ammonia, ternary $\mathrm{H}_{2} \mathrm{SO}_{4}-\mathrm{H}_{2} \mathrm{O}-\mathrm{NH}_{3}$ nucleation is the preferred nucleation mechanism (Korhonen et al., 1999). This is confirmed by recent field studies: Results from the Pittburgh Air Quality Study (PAQS, 2002) showed that binary $\mathrm{H}_{2} \mathrm{SO}_{4}$ $\mathrm{H}_{2} \mathrm{O}$ nucleation alone can not explain the observed nucleation rates (Stanier et al., 2004) and that ternary $\mathrm{H}_{2} \mathrm{SO}_{4}$ $\mathrm{H}_{2} \mathrm{O}-\mathrm{NH}_{3}$ nucleation can predict accurately the presence or lack of nucleation (Gaydos et al., 2005). During the ANAR$\mathrm{ChE}$ experiment in Atlanta, Georgia, McMurry et al. (2005), who measured also gas-phase $\mathrm{H}_{2} \mathrm{SO}_{4}$ and $\mathrm{NH}_{3}$, found that nucleation occurred when $\mathrm{H}_{2} \mathrm{SO}_{4}$ concentrations exceeded $5 \times 10^{5} \mathrm{~cm}^{3}$, and that the number of newly formed particles is sensitive to ammonia mixing ratios. Birmili et al. (2000) estimated that for ternary particle formation in the Hohenpeissenberg environment a concentration $\mathrm{H}_{2} \mathrm{SO}_{4}$ in the range of $1-2 \times 10^{7} \mathrm{~cm}^{-3}$ is required.

During HAZE, on 18 May 2002, the $\mathrm{H}_{2} \mathrm{SO}_{4}$ concentrations reached up to $1.9 \times 10^{7} \mathrm{~cm}^{3}$ and coincided with high ultra fine particle concentrations of up to $1.1 \times 10^{4} \mathrm{~cm}^{-3}$. 


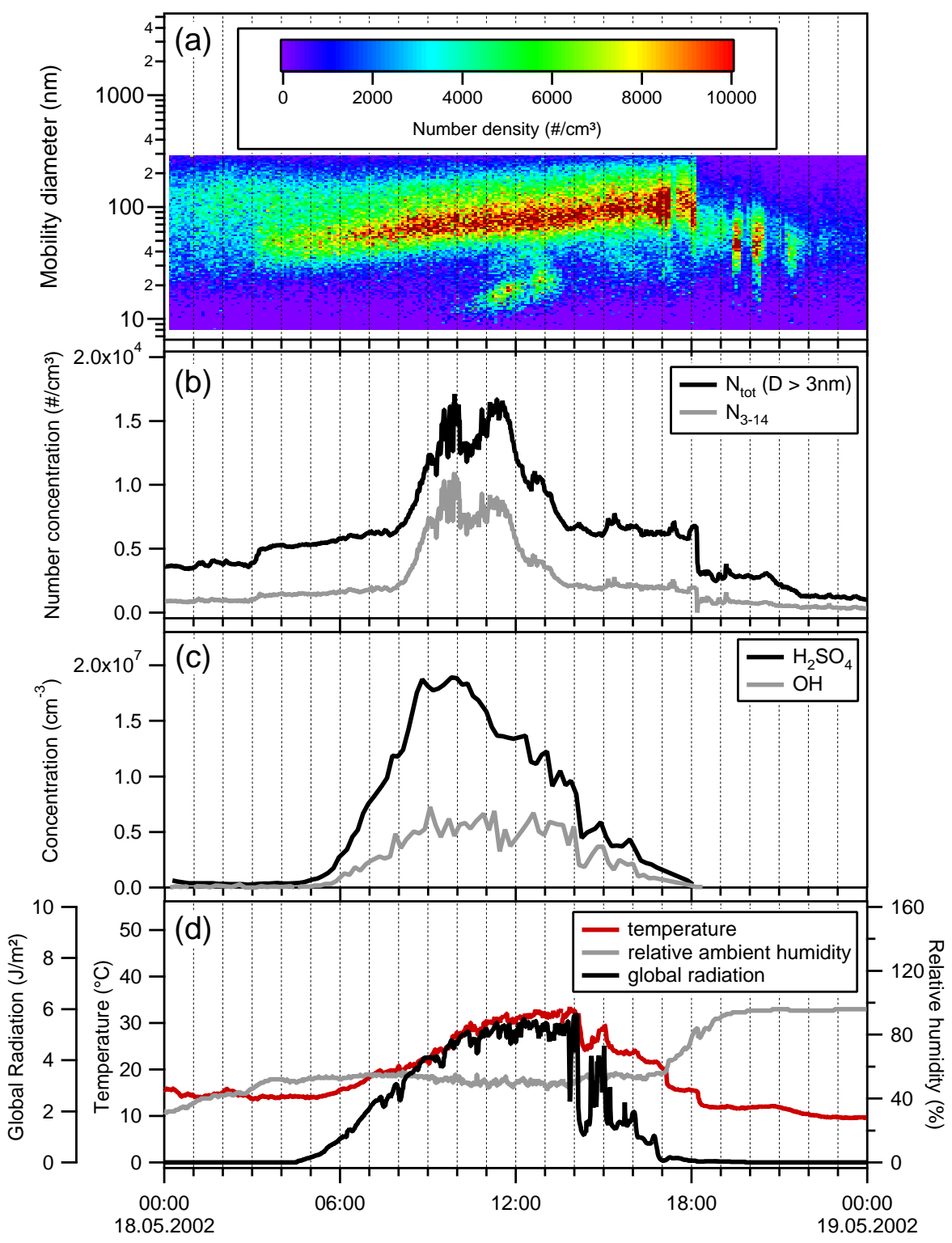

Fig. 12. Nucleation event on 18 May 2002. (a), (b) Particle number density; (c) Gas-phase concentration of $\mathrm{H}_{2} \mathrm{SO}_{4}$ and $\mathrm{OH}_{\text {; }}$ (d) Global radiation, temperature, and relative humidity.

On 21 May 2002, $\mathrm{H}_{2} \mathrm{SO}_{4}$ concentrations reached up to $6 \times 10^{6} \mathrm{~cm}^{-3}$. We estimate the particle formation rate of particles between 3 and $14 \mathrm{~nm}, J_{3-14}$, by dividing the number increase of particles between 3 and $14 \mathrm{~nm}$ by its corresponding duration. From the values obtained above from Panel (b) in Fig. 12 we infer an average rate $J_{3-14}$ of $\approx 1.2 \mathrm{~cm}^{3} \mathrm{~s}^{1}$ for the nucleation event on 18 May 2002, and from Panel (b) in Fig. 13 a rate of $\approx 0.6 \mathrm{~cm}^{-3} \mathrm{~s}^{-1}$ for 21 May 2002. Korhonen et al. (1999) presented calculations for the ternary $\mathrm{H}_{2} \mathrm{SO}_{4} / \mathrm{H}_{2} \mathrm{O} / \mathrm{NH}_{3}$ nucleation from which we can infer that at an $\mathrm{H}_{2} \mathrm{SO}_{4}$ concentration of $6 \times 10^{6} \mathrm{~cm}^{-3}$ and a temperature of $298 \mathrm{~K}$, significant nucleation can be expected for
$\mathrm{NH}_{3}$ concentrations above 40 ppt. The ambient $\mathrm{NH}_{3}$ concentration at the Hohenpeissenberg area certainly exceeds this value, because the surrounding area of Hohenpeissenberg is mainly used for agriculture.

Summarizing, the observed new particle formation during HAZE2002 can be explained by ternary $\mathrm{H}_{2} \mathrm{SO}_{4}-\mathrm{H}_{2} \mathrm{O}-\mathrm{NH}_{3}$ nucleation, a conclusion that is in agreement with previous observations at Hohenpeissenberg by Birmili et al. (2003), and also with observations reported by Zhang et al. (2004) on nucleation events at Pittsburgh, USA. However, our data do not allow to rule out that organic species were involved in the nucleation. 


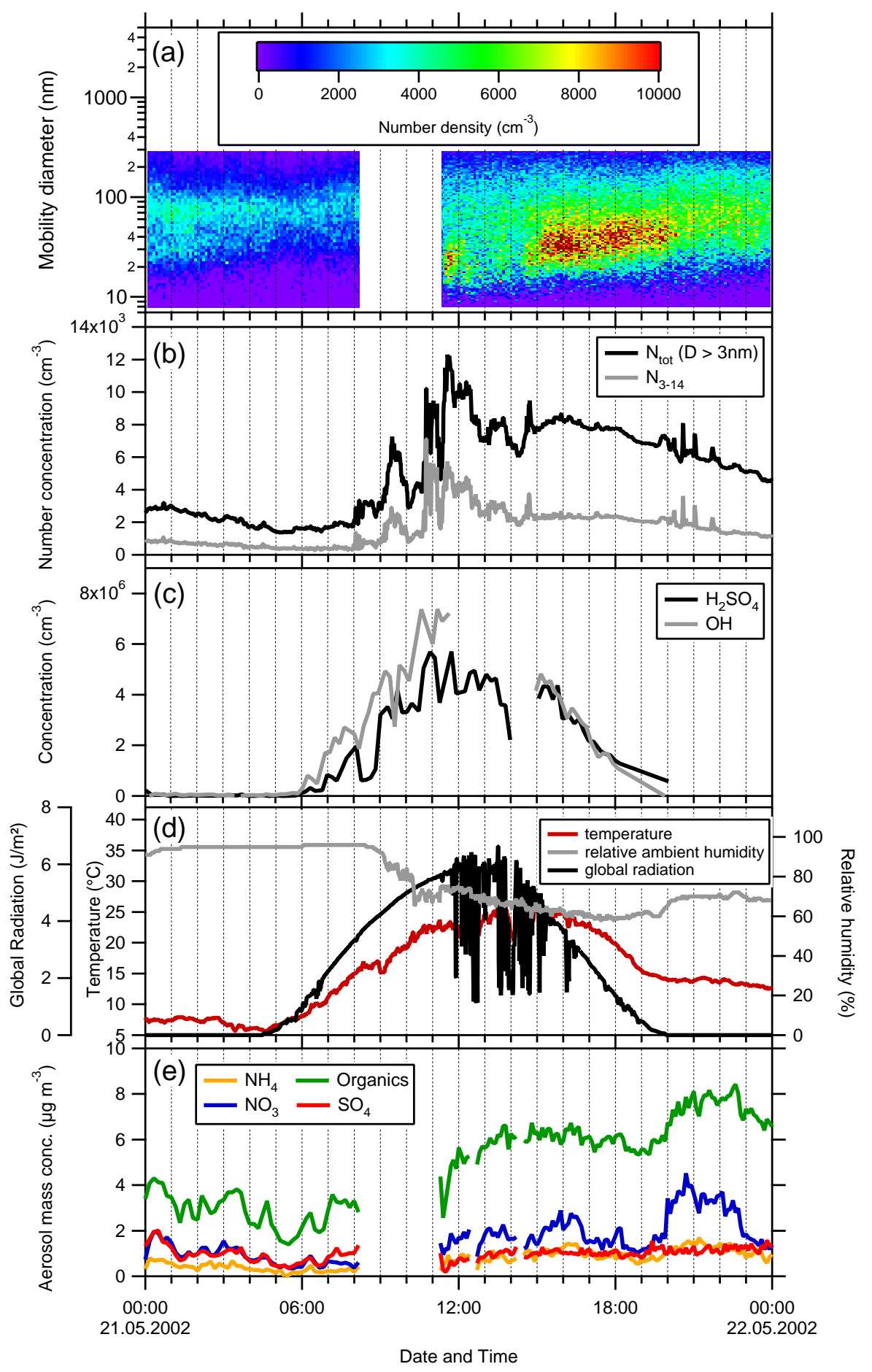

Fig. 13. Nucleation event on 21 May 2002. (a), (b) Particle number density; (c) Gas-phase concentration of $\mathrm{H}_{2} \mathrm{SO}_{4}$ and $\mathrm{OH}_{\text {; }}$ (d) $\mathrm{Global}$ radiation, temperature, and relative humidity; (e) Aerosol mass concentrations measured with the Q-AMS.

The aerosol mass concentrations measured by the Q-AMS on 21 May 2002 (Fig. 13, Panel (e) can give information on further particle growth. The mass concentrations show an increase of all species between 11:00 and 14:00. This finding suggests that not only the species that trigger the nucleation $\left(\mathrm{H}_{2} \mathrm{SO}_{4}, \mathrm{NH}_{3}\right)$, but also all other condensable species are involved in the particle growth, especially organic substances and nitrate. From data measured at Pittsburgh, Zhang et al. (2004) inferred that besides $\mathrm{H}_{2} \mathrm{SO}_{4}$ and $\mathrm{NH}_{3}$, only organic species contributed to the particle growth, while nitrate plays only a minor role in particle growth. In a remote region (Hyytiälä, Finland), Allan et al. (2006) observed that 
the growing particles following nucleation events were exclusively organic in nature during the early stages of their evolution. Observations on Appledore Island, Maine, during ICARTT/CHAiOS 2004 also showed that condensation of organic species is an important process for nanoparticle growth (Russel et al., 2007). These findings are different from the observations made on 21 May during HAZE, because as can be seen in Panel (e) of Fig. 13, nitrate appears to be an important constituent of the growing particles. Apparently, the availability of condensable species in the gas phase determines the composition of the growing particles following nucleation events.

\section{Summary and conclusion}

Microphysical properties and chemical composition of rural continental aerosol particles have been measured during HAZE2002 with a wide range of instrumentation. The data yielded size-resolved information on the chemical composition of the aerosol phase at a typical rural site in central Europe which also serves as a global GAW station.

Comparison between gravimetrically determined PM2.5 and mass spectrometrically determined non-refractory PM1 showed that on average $62 \%$ of PM2.5 was non-refractory PM1 material. The non-refractory PM1 was composed to $50 \%$ of organic and $50 \%$ of inorganic components. The rural continental organic aerosol was identified as being composed mainly of oxygenated aerosol from both the comparison of OM1 and OC2.5 (ratio: $2.1 \pm 1.4$ ) as well as from the mass spectrometric composition: The multicomponent analysis of the Q-AMS data showed that the organic aerosol was only to about $(20 \pm 17) \%$ composed of hydrocarbon-like organic aerosol, indicating the low influence of fresh anthropogenic emissions on the measurement site. The oxygenated organic aerosol was found to be composed partly of an aged component, similar to organic aerosol observed in the free troposphere, but dominated by an aerosol type that resembled secondary organic aerosol from chamber experiments. The conclusion that the organic aerosol was dominated by SOA was confirmed by the diurnal cycle of the organic aerosol, indicating SOA production during during sunlight hours.

The high abundance of proteins $(\sim 3 \%)$ indicated a high proportion of primary biological material $(\sim 30 \%)$ in PM2.5. The low abundance of PAHs $\left(<1 \mathrm{ng} \mathrm{m}^{-3}\right)$ and EC $\left(<1 \mu \mathrm{g} \mathrm{m}^{-3}\right)$ in PM2.5 confirmed the low contribution of combustion emissions, which are usually also major sources for HOA. The influence of polluted air masses originating from the Po Valley, Italy, was clearly detectable during an episode and was confirmed by trajectory calculations.

The comparison between the mass size distribution measured with the Q-AMS and the mass size distributions inferred from SMPS and OPC data showed good agreement if the density inferred from the chemical composition was used to convert volume into mass and vacuum aerodynamic diameter into volume equivalent diameter. The refractive index of the aerosol particle was found to be around 1.40-1.45. Wet removal of aerosol particles were investigated during a precipitation event. It was found that ammonium nitrate is most efficiently removed, while organics compounds were less efficiently removed, especially small organic particles. Furthermore, ammonium nitrate was observed to partition into the gas phase at temperatures above $293 \mathrm{~K}$, while below $293 \mathrm{~K}$, the ammonium mass fraction of the non-refractory PM1 remained almost constant at about $25 \%$.

New particle formation events were observed during HAZE2002 (18 May 2002 and 21 May 2002). During these nucleation events particle number densities exceeding $10^{4} \mathrm{~cm}^{-3}$ in the nucleation mode $(3-14 \mathrm{~nm})$ were observed along with high sulfuric acid concentrations $\left(\sim 6 \times 10^{6} \mathrm{~cm}^{-3}\right)$. The observed particle formation rates and sulfuric acid concentrations and the estimated abundance of $\mathrm{NH}_{3}$ are in agreement with calculated nucleation threshold for ternary nucleation and are also consistent with a previous long-term study and calculations.

Summarizing, it was found that the rural continental aerosol in spring 2002 at Hohenpeissenberg was very little influenced by fresh anthropogenic emissions, but mainly dominated by regional and long range transport. The organic aerosol compounds were highly oxidized (OOA to HOA ratio of 4:1), and contained around $30 \%$ primary biological material. Natural aerosol sources appear to play a major role in rural continental aerosol not only in the supermicron but also in the submicron size range. Since the measurement station was isolated from ground based sources due to a stable inversion layer during night-time, it can be concluded that these natural sources are important not only on a local but also on a regional scale.

Acknowledgements. We would like to thank T. Böttger and the GAW/MOHp staff for technical and data support during the campaign. T. Elste and G. Stange performed the $\mathrm{OH}$ and $\mathrm{H}_{2} \mathrm{SO}_{4}$ measurements, U. Kaminski provided the GAW/MOHp particle data, S. Gilge the trace gas data. We also thank T. Vetter for providing the Mie scattering program, J. D. Allan and all contributors for the Q-AMS evaluation software, Q. Zhang (SUNY, Albany) for the multicomponent analysis, and V. Lanz (EMPA, Switzerland) as well as two anonymous reviewers for many helpful comments. T. Franze, C. Schauer, and U. Pöschl gratefully acknowledge funding by the German Federal Ministry of Education and Research (BMBF - AFO2000 CARBAERO) and support by R. Leube, S. Mahler, R. Niessner, and A. Zerrath.

Edited by: J. Thornton 


\section{References}

Alfarra, M. R., Coe, H., Allan, J. D., Bower, K. N., Boudries, H., Canagaratna, M. R., Jimenez, J. L., Jayne, J. T., Garforth, A. A., Li, S. M., and Worsnop, D. R.: Characterization of urban and rural organic particulate in the Lower Fraser Valley using two Aerodyne Aerosol Mass Spectrometers, Atmos. Environ., 38, 5745-5758, 2004.

Alfarra, M. R., Prévôt, A. S. H., Szidat, S., Sandradewi, J., Weimer, S., Lanz, V. A., Schreiber, D., Mohr, M., and Baltensperger, U.: Identification of the Mass Spectral Signature of Organic Aerosols from Wood Burning Emissions, Environ. Sci. Technol., 41, 5770-5777, 2007.

Allan, J. D., Bower, K. N., Coe, H., Boudries, H., Jayne, J. T., Canagaratna, M. R., Millet, D. B., Goldstein, A. H., Quinn, P. K., Weber, R. J., and Worsnop, D. R.: Submicron aerosol composition at Trinidad Head, California, during ITCT 2K2: Its relationship with gas phase volatile organic carbon and assessment of instrument performance, J. Geophys. Res.-Atmos., 109, D13S24, doi:10.1029/2003JD004208, 2004a.

Allan, J. D., Delia, A. E., Coe, H., Bower, K. N., Alfarra, M. R., Jimenez, J. L., Middlebrook, A. M., Drewnick, F., Onasch, T. B., Canagaratna, M. R., Jayne, J. T., and Worsnop, D. R.: A generalised method for the extraction of chemically resolved mass spectra from Aerodyne aerosol mass spectrometer data, J. Aerosol Sci., 35, 909-922, doi:10.1016/j.jaerosci.2004.02.007, 2004b.

Allan, J. D., Jimenez, J. L., Williams, P. I., Alfarra, M. R., Bower, K. N., Jayne, J. T., Coe, H., and Worsnop, D. R.: Quantitative sampling using an Aerodyne aerosol mass spectrometer - 1 . Techniques of data interpretation and error analysis, J. Geophys. Res.-Atmos., 108, 4090, doi:10.1029/2002JD002358, 2003.

Allan, J. D.,Alfarra, M. R., Bower, K. N., Coe, H. Jayne, J. T., Worsnop, D. R., Aalto, P. P.. Kulmala, M., Hyötyläinen, T., Cavalli, F., and Laaksonen, A.: Size and composition measurements of background aerosol and new particle growth in a Finnish forest during QUEST 2 using an Aerodyne Aerosol Mass Spectrometer, Atmos. Chem. Phys., 6, 315-327, 2006,

http://www.atmos-chem-phys.net/6/315/2006/.

Allen, A. G., Harrison, R. M., and Wake, M. T.: A meso-scale study of the behavior of atmospheric ammonia and ammonium, Atmos. Environ., 22, 1347-1353, 1988.

Bae, M.-S., Demerjian, K. L., and Schwab, J. J.: Seasonal estimation of organic mass to organic carbon in PM2.5 at rural and urban locations in New York state, Atmos. Environ., 40, 74677479, 2006.

Banner, M. J., Mattick, L. R., Splittstoesser, D. F.: Chemical composition of the ascospores of Byssochlamys fulva, J. Food Sci., 44, 545-548, 1979.

Berndt, T., Böge, O., Stratmann, F., Heintzenberg, J., and Kulmala, M.: Rapid formation of sulfuric acid particles at nearatmospheric conditions, Science, 307, 698-700, 2005.

Berresheim, H., Elste, T., Plass-Dülmer, C., Eisele, F. L., and Tanner, D. J.: Chemical ionization mass spectrometer for longterm measurements of atmospheric $\mathrm{OH}$ and $\mathrm{H}_{2} \mathrm{SO}_{4}$, International Journal of Mass Spectrometry, 202, 91-109, 2000.

Birmili, W., Berresheim, H., Plass-Dülmer, C., Elste, T., Gilge, S., Wiedensohler, A., and Uhrner, U.: The Hohenpeissenberg aerosol formation experiment (HAFEX): a long-term study including size-resolved aerosol, $\mathrm{H} 2 \mathrm{SO} 4, \mathrm{OH}$, and monoterpenes measurements, Atmos. Chem. Phys., 3, 361-376, 2003, http://www.atmos-chem-phys.net/3/361/2003/.

Birmili, W., Wiedensohler, A., Plass-Dülmer, C., and Berresheim, H.: Evolution of newly formed aerosol particles in the continental boundary layer: A case study including $\mathrm{OH}$ and $\mathrm{H}_{2} \mathrm{SO}_{4}$ measurements, Geophys. Res. Lett., 27, 2205-2208, 2000.

Bohren, C. F. and Huffmann, D. R.: Absorption and scattering of light by small particles, Wiley and Sons, New York, 1983.

Bonn, B. and Moortgat, G. K.: New particle formation during alpha- and beta-pinene oxidation by $\mathrm{O}_{3}, \mathrm{OH}$ and $\mathrm{NO}_{3}$, and the influence of water vapour: particle size distribution studies, Atmos. Chem. Phys., 2, 183-196, 2002, http://www.atmos-chem-phys.net/2/183/2002/.

Bonn, B. and Moortgat, G. K.: Sesquiterpene ozonolysis: Origin of atmospheric new particle formation from biogenic hydrocarbons, Geophys. Res. Lett., 30, 1585, doi:10.1029/2003GL017000, 2003.

Briza, P., Ellinger, A., , Winkler, G., and Breitenbach, M.: Chemical Composition of the Yeast Ascospore Wall, Journal of Biological Chemistry, 263, 11 569-11 574, 1988.

Broekhuizen, K., Chang, R. Y.-W., Leaitch, W. R., Li, S.-M., and Abbatt, J. P. D.: Closure between measured and modeled cloud condensation nuclei $(\mathrm{CCN})$ using size-resolved aerosol compositions in downtown Toronto, Atmos. Chem. Phys., 6, 2513-2524, 2006, http://www.atmos-chem-phys.net/6/2513/2006/.

Canagaratna, M. R., Jayne, J. T., Ghertner, D. A., Herndon, S., Shi, Q., Jimenez, J. L., Silva, P. J., Williams, P., Lanni, T., Drewnick, F., Demerjian, K. L., Kolb, C. E., and Worsnop, D. R.: Chase studies of particulate emissions from in-use New York City vehicles, Aerosol Sci. Technol., 38, 555-573, 2004.

Canagaratna, M. R., Jayne, J. T., Jimenez, J. L., Allan, J. D., Alfarra, M. R., Zhang, Q., Onasch, T. B., Drewnick, F., Coe, H., Middlebrook, A., Delia, A., Williams, L. R., Trimborn, A. M., Northway, M. J., DeCarlo, P. F., Kolb, C. E., Davidovits, P., and Worsnop, D. R.: Chemical and microphysical characterization of ambient aerosols with the Aerodyne aerosol mass spectrometer, Mass Spectrometry Reviews, 26, 185-222, 2007.

Cubison, M. J., Alfarra, M. R., Allan, J., Bower, K. N., Coe, H., McFiggans, G. B., Whitehead, J. D., Williams, P. I., Zhang, Q., Jimenez, J. L., Hopkins, J., and Lee, J.: The characterisation of pollution aerosol in a changing photochemical environment, Atmos. Chem. Phys., 6, 5573-5588, 2006, http://www.atmos-chem-phys.net/6/5573/2006/.

Curtius, J.: Nucleation of atmospheric aerosol particles, Comptes Rendus Physique, 7, 1027-1045, 2006.

DeCarlo, P. F., Slowik, J. G., Worsnop, D. R., Davidovits, P., and Jimenez, J. L.: Particle morphology and density characterization by combined mobility and aerodynamic diameter measurements. Part 1: Theory, Aerosol Sci. Technol., 38, 1185-1205, 2004.

Despres, V., Nowoisky, J., Klose, M., Conrad, R., Andreae, M. O., and Pöschl, U.: Characterization of primary biogenic aerosol particles in urban, rural, and high-alpine air by DNA sequence and restriction fragment analysis of ribosomal RNA genes, Biogeosciences, 4, 1127-1141, 2007, http://www.biogeosciences.net/4/1127/2007/.

Drewnick, F., Jayne, J. T., Canagaratna, M., Worsnop, D. R., and Demerjian, K. L.: Measurement of ambient aerosol composition during the PMTACS-NY 2001 using an aerosol mass spectrome- 
ter. Part II: Chemically speciated mass distributions, Aerosol Sci. Technol., 38, 104-117, 2004.

Dusek, U., Frank, G. P., Hildebrandt, L., Curtius, J., Schneider, J., Walter, S., Chand, D., Drewnick, F., Hings, S., Jung, D., Borrmann, S., and Andreae, M. O.: Size matters more than chemistry for cloud-nucleating ability of aerosol particles, Science, 312, 1375-1378, 2006.

El-Zanan, H. S., Lowenthal, D. H., Zielinska, B., Chow, J. C., and Kumar, N.: Determination of the organic aerosol mass to organic carbon ratio in IMPROVE samples, Chemosphere, 60, 485-496, 2005.

Elbert, W., Taylor, P. E., Andreae, M. O., and Pöschl, U.: Contribution of fungi to primary biogenic aerosols in the atmosphere: wet and dry discharged spores, carbohydrates, and inorganic ions, Atmos. Chem. Phys., 7, 4569-4588, 2007,

http://www.atmos-chem-phys.net/7/4569/2007/.

Fehrenbach, T.: Analyse von Aminosäuren, Proteinen und Nitroderivaten in atmosphärischen Aerosolen und in Straßenstaub, Technical University of Munich, Munich, 2006.

Franze, T.: Analyse und Reaktivität von Proteinen in Atmosphärischen Aerosolen und Entwicklung neuer Immunoassays zur Messung von Nitroproteinen, Technical University of Munich, Munich, 2004.

Franze, T., Weller, M. G., Niessner, R., and Pöschl, U.: Protein nitration by polluted air, Environ. Sci. Technol., 39, 1673-1678, 2005.

Fuzzi, S., Andreae, M. O., Huebert, B. J., Kulmala, M., Bond, T. C., Boy, M., Doherty, S. J., Guenther, A., Kanakidou, M., Kawamura, K., Kerminen, V. M., Lohmann, U., Russell, L. M., and Pöschl, U.: Critical assessment of the current state of scientific knowledge, terminology, and research needs concerning the role of organic aerosols in the atmosphere, climate, and global change, Atmos. Chem. Phys., 6, 2017-2038, 2006,

http://www.atmos-chem-phys.net/6/2017/2006/.

GCEP: An Assessment of Biomass Feedstock and Conversion Research Opportunities, Global Climate and Energy Project, Stanford University, http://gcep.stanford.edu, 2005.

Gelencsér, A.: Carbonaceous Aerosol, Springer, Dordrecht, 2004.

Gilardoni, S., Russell, L. M., Sorooshian, A., Flagan, R. C., Seinfeld, J. H., Bates, T. S., Quinn, P. K., Allan, J. D., Williams, B., Goldstein, A. H., Onasch, T. B., and Worsnop, D. R., Regional variation of organic functional groups in aerosol particles on four U.S. east coast platforms during the International Consortium for Atmospheric Research on Transport and Transformation 2004 campaign, J. Geophys. Res., 112, D10S27, doi:10.1029/2006JD007737, 2007.

Graber, E. R. and Rudich, Y.: Atmospheric HULIS: How humiclike are they? A comprehensive and critical review, Atmos. Chem. Phys., 6, 729-753, 2006,

http://www.atmos-chem-phys.net/6/729/2006/.

Hinds, W. C.: Aerosol technology -Properties, behavior, and measurement of airborne particles, Wiley and Sons, New York, 1999.

Hudson, J. G.: Variability of the relationship between particle size and cloud-nucleating ability, Geophys. Res. Lett., 34, L08801, doi:10.1029/2006GL028850, 2007.

Ivleva, N. P., McKeon, U., Niessner, R., and Pöschl, U.: Raman microspectroscopic analysis of size-resolved atmospheric aerosol particle samples collected with an ELPI: Soot, humic-like substances, and inorganic compounds, Aerosol Sci. Technol., 41,
655-671, 2007.

Jaenicke, R.: Abundance of cellular material and proteins in the atmosphere, Science, 308, 73-73, 2005.

Jayne, J. T., Leard, D. C., Zhang, X. F., Davidovits, P., Smith, K. A., Kolb, C. E., and Worsnop, D. R.: Development of an aerosol mass spectrometer for size and composition analysis of submicron particles, Aerosol Sci. Technol., 33, 49-70, 2000.

Jimenez, J. L., Bahreini, R., Cocker, D. R., Zhuang, H., Varutbangkul, V., Flagan, R. C., Seinfeld, J. H., O'Dowd, C. D., and Hoffmann, T.: New particle formation from photooxidation of diiodomethane $\left(\mathrm{CH}_{2} \mathrm{I}_{2}\right)$, J. Geophys. Res.-Atmos., 108(D10), 4318, doi:10.1029/2002JD002452, 2003 a.

Jimenez, J. L., Jayne, J. T., Shi, Q., Kolb, C. E., Worsnop, D. R., Yourshaw, I., Seinfeld, J. H., Flagan, R. C., Zhang, X. F., Smith, K. A., Morris, J. W., and Davidovits, P.: Ambient aerosol sampling using the Aerodyne Aerosol Mass Spectrometer, J. Geophys. Res.-Atmos., 108(D10), 8425, doi:10.1029/2001JD001213, 2003b.

Kanakidou, M., Seinfeld, J. H., Pandis, S. N., Barnes, I., Dentener, F. J., Facchini, M. C., Van Dingenen, R., Ervens, B., Nenes, A., Nielsen, C. J., Swietlicki, E., Putaud, J. P., Balkanski, Y., Fuzzi, S., Horth, J., Moortgat, G. K., Winterhalter, R., Myhre, C. E. L., Tsigaridis, K., Vignati, E., Stephanou, E. G., and Wilson, J.: Organic aerosol and global climate modelling: a review, Atmos. Chem. Phys., 5, 1053-1123, 2005,

http://www.atmos-chem-phys.net/5/1053/2005/.

Korhonen, P., Kulmala, M., Laaksonen, A., Viisanen, Y., McGraw, R., and Seinfeld, J. H.: Ternary nucleation of $\mathrm{H}_{2} \mathrm{SO}_{4}, \mathrm{NH}_{3}$, and $\mathrm{H}_{2} \mathrm{O}$ in the atmosphere, J. Geophys. Res.-Atmos., 104, 26349 26353, 1999.

Kulmala, M., Vehkamaki, H., Petajda, T., Dal Maso, M., Lauri, A., Kerminen, V. M., Birmili, W., and McMurry, P. H.: Formation and growth rates of ultrafine atmospheric particles: a review of observations, J. Aerosol Sci., 35, 143-176, 2004.

Lanz, V. A., Alfarra, M. R., Baltensperger, U., Buchmann, B., Hueglin, C., and Prévôt, A. S. H.: Source apportionment of submicron organic aerosols at an urban site by factor analytical modelling of aerosol mass spectra, Atmos. Chem. Phys., 7, 1503-1522, 2007

Lim, H. J. and Turpin, B. J.: Origins of primary and secondary organic aerosol in Atlanta: Results of time-resolved measurements during the Atlanta supersite experiment, Environ. Sci. Technol., 36, 4489-4496, 2002.

Lohmann, U. and Feichter, J.: Global indirect aerosol effects: a review, Atmos. Chem. Phys., 5, 715-737, 2005, http://www.atmos-chem-phys.net/5/715/2005/.

Marr, L. C., Dzepina, K., Jimenez, J. L., Reisen, F., Bethel, H. L., Arey, J., Gaffney, J. S., Marley, N. A., Molina, L. T., and Molina, M. J.: Sources and transformations of particle-bound polycyclic aromatic hydrocarbons in Mexico City, Atmos. Chem. Phys., 6, 1733-1745, 2006, http://www.atmos-chem-phys.net/6/1733/2006/.

McFiggans, G., Artaxo, P., Baltensperger, U., Coe, H., Facchini, M. C., Feingold, G., Fuzzi, S., Gysel, M., Laaksonen, A., Lohmann, U., Mentel, T. F., Murphy, D. M., O’Dowd, C. D., Snider, J. R., and Weingartner, E.: The effect of physical and chemical aerosol properties on warm cloud droplet activation, Atmos. Chem. Phys., 6, 2593-2649, 2006,

http://www.atmos-chem-phys.net/6/2593/2006/. 
McLafferty, F. W. and Turecek, F.: Interpretation of mass spectra, University Science Books, Sausalito, 1992.

McMurry, P. H., M. Fink, M., Sakurai, H., Stolzenburg, M. R., Mauldin III, R. L., Smith, J., Eisele, F., Moore, K., Sjostedt, S., Tanner, D., Huey, L. G., Nowak, J. B., Edgerton, E., and Voisin, D.: A criterion for new particle formation in the sulfur-rich Atlanta atmosphere, J. Geophys. Res., 110, D22S02, doi:10.1029/2005JD005901, 2005.

Meszaros, E. and Horvath, L.: Concentration and dry deposition of atmospheric sulfur and nitrogen-compounds in Hungary, Atmos. Environ., 18, 1725-1730, 1984.

Mikhailov, E., Vlasenko, S., Niessner, R., and Pöschl, U.: Interaction of aerosol particles composed of protein and salts with water vapor: hygroscopic growth and microstructural rearrangement, Atmos. Chem. Phys., 4, 323-350, 2004,

http://www.atmos-chem-phys.net/4/323/2004/.

Morino, Y., Kondo, Y., Takegawa, N., Miyazaki, Y., Kita, K., Komazaki, Y., Fukuda, M., Miyakawa, T., Moteki, N., and Worsnop, D. R.: Partitioning of $\mathrm{HNO}_{3}$ and particulate nitrate over Tokyo: Effect of vertical mixing, J. Geophys. Res.-Atmos., 111, D15215, doi:10.1029/2005JD006887, 2006.

Mozurkewich, M.: The dissociation-constant of ammoniumnitrate and its dependence on temperature, relative-humidity and particle-size, Atmos. Environ., 27, 261-270, 1993.

Oberdörster, G.: Pulmonary effects of inhaled ultrafine particles, Int. Arch. Occup. Environ. Health, 74, 1-8, 2001.

Penner, J. E., Quaas, J., Storelvmo, T., Takemura, T., Boucher, O., Guo, H., Kirkevåg, A., Kristjánsson, J. E., and Seland, Ø.: Model intercomparison of indirect aerosol effects, Atmos. Chem. Phys., 6, 3391-3405, 2006,

http://www.atmos-chem-phys.net/6/3391/2006/.

Pope, C. A., Burnett, R. T., Thun, M. J., Calle, E. E., Krewski, D., Ito, K., and Thurston, G. D.: Lung cancer, cardiopulmonary mortality, and long-term exposure to fine particulate air pollution, JAMA, 287, 1132-1141, 2002.

Pope, C. A. and Dockery, D. W.: Health effects of fine particulate air pollution: Lines that connect, J. Air Waste Manage. Assoc., 56, 709-742, 2006.

Pöschl, U.: Atmospheric aerosols: Composition, transformation, climate and health effects, Angewandte Chemie-International Edition, 44, 7520-7540, 2005.

Rogge, W. F., Hildemann, L. M., Mazurek, M. A., Cass, G. R., and Simoneit, B. R. T.: Sources of fine organic aerosol. 9. Pine, oak and synthetic log combustion in residential fireplaces, Environ. Sci. Technol., 32, 13-22, 1998.

Römpp, A.: Analysis of organic compounds in atmospheric aerosols by liquid chromatography-high resolution mass spectrometry (LC/MS/MS-ToF): Method development and applications. Johannes Gutenberg University, Mainz, 2003.

Russell, L. M..: Aerosol Organic-Mass-to-Organic-Carbon Ratio Measurements, Environ. Sci. Technol., 37, 2982-2987, 2003.

Russell, L. M., Mensah, A. A., Fischer, E. V., Sive, B. C., Varner, R. K., Keene, W. C., Stutz, J., and Pszenny, A. A. P.: Nanoparticle growth following photochemical a- and b-pinene oxidation at Appledore Island during International Consortium for Research on Transport and Transformation/Chemistry of Halogens at the Isles of Shoals 2004, J. Geophys. Res., 112, D10S21, doi:10.1029/2006JD007736, 2007.

Schauer, C., Niessner, R., and Pöschl, U.: Analysis of nitrated poly- cyclic aromatic hydrocarbons by liquid chromatography with fluorescence and mass spectrometry detection: air particulate matter, soot, and reaction product studies, Anal. Bioanal. Chem., 378, 725-736, 2004.

Schauer, C., Niessner, R., and Pöschl, U.: Polycyclic aromatic hydrocarbons in urban air particulate matter: Decadal and seasonal trends, chemical degradation, and sampling artifacts, Environ. Sci. Technol., 37, 2861-2868, 2003a.

Schauer, J. J., Mader, B. T., Deminter, J. T., Heidemann, G., Bae, M. S., Seinfeld, J. H., Flagan, R. C., Cary, R. A., Smith, D., Huebert, B. J., Bertram, T., Howell, S., Kline, J. T., Quinn, P., Bates, T., Turpin, B., Lim, H. J., Yu, J. Z., Yang, H., and Keywood, M. D.: ACE-Asia intercomparison of a thermal-optical method for the determination of particle-phase organic and elemental carbon, Environ. Sci. Technol., 37, 993-1001, 2003 b.

Schneider, J., Weimer, S., Drewnick, F., Borrmann, S., Helas, G., Gwaze, P., Schmid, O., Andreae, M. O., and Kirchner, U.: Mass spectrometric analysis and aerodynamic properties of various types of combustion-related aerosol particles, Int. J. Mass Spectrometry, 258, 37-49, 2006.

Seinfeld, J. H. and Pankow, J. F.: Organic atmospheric particulate material, Ann. Rev. Phys. Chem., 54, 121-140, 2003.

Sharma, H., Jain, V. K., and Khan, Z. H.: Characterization and source identification of polycyclic aromatic hydrocarbons (PAHs) in the urban environment of Delhi, Chemosphere, 66, 302-310, 2007.

Stelson, A. W. and Seinfeld, J. H.: Relative-humidity and temperature-dependence of the ammonium-nitrate dissociationconstant, Atmos. Environ., 16, 983-992, 1982.

Stier, P., Seinfeld, J. H., Kinne, S., and Boucher, O.: Aerosol absorption and radiative forcing, Atmos. Chem. Phys., 7, 52375261, 2007, http://www.atmos-chem-phys.net/7/5237/2007/.

Takegawa, N., Miyazaki, Y., Kondo, Y., Komazaki, Y., Miyakawa, T., Jimenez, J. L., Jayne, J. T., Worsnop, D. R., Allan, J. D., and Weber, R. J.: Characterization of an Aerodyne Aerosol Mass Spectrometer (AMS): Intercomparison with other aerosol instruments, Aerosol Sci. Technol., 39, 760-770, 2005.

Turpin, B. J. and Lim, H. J.: Species contributions to PM2.5 mass concentrations: Revisiting common assumptions for estimating organic mass, Aerosol Sci. Technol., 35, 602-610, 2001.

Umhauer, H.: Particle-size distribution analysis by scattered-light measurements using an optically defined measuring volume, J. Aerosol Sci., 14, 765-770, 1983.

Warnke, J., Bandur, R., and Hoffmann, T.: Capillary-HPLC-ESIMS/MS method for the determination of acidic products from the oxidation of monoterpenes in atmospheric aerosol samples, Anal. Bioanal. Chem., 385, 34-45, 2006.

Weimer, S., Drewnick, F., Hogrefe, O., Schwab, J. J., Rhoads, K., Orsini, D., Canagaratna, M., Worsnop, D. R., and Demerjian, K. L.: Size-selective nonrefractory ambient aerosol measurements during the Particulate Matter Technology Assessment and Characterization Study -New York 2004 Winter Intensive in New York City, J. Geophys. Res.-Atmos., 111, D18305, doi:10.1029/2006JD007215, 2006.

Willison, M. J., Clarke, A. G., and Zeki, E. M.: Seasonal-variation in atmospheric aerosol concentration and composition at urban and rural sites in Northern England, Atmos. Environ., 19, 10811089, 1985. 
Yu, H., Kaufman, Y. J., Chin, M., Feingold, G., Remer, L. A., Anderson, T. L., Balkanski, Y., Bellouin, N., Boucher, O., Christopher, S., DeCola, P., Kahn, R., Koch, D., Loeb, N., Reddy, M. S., Schulz, M., Takemura, T., and Zhou, M.: A review of measurement-based assessments of the aerosol direct radiative effect and forcing, Atmos. Chem. Phys., 6, 613-666, 2006, http://www.atmos-chem-phys.net/6/613/2006/.

Yu, L. E., Shulman, M. L., Kopperud, R., and Hildemann, L. M.: Fine organic aerosols collected in a humid, rural location (Great Smoky Mountains, Tennessee, USA): Chemical and temporal characteristics, Atmos. Environ., 39, 6037-6050, 2005.

Zhang, Q. and Anastasio, C.: Free and combined amino compounds in atmospheric fine particles (PM2.5) and fogwaters from northern California, Atmos. Environ., 37, 2247-2258, 2003.

Zhang, J., Chameides, W. L., Weber, R., Cass, G., Orsini, D., Edgerton, E. S., Jongejan, P., and Slanina, J.: An evaluation of the thermodynamic equilibrium assumption for fine particulate composition: Nitrate and ammonium during the 1999 Atlanta Supersite Experiment, J. Geophys. Res., 108, 8414, doi:10.1029/2001JD001592, 2003.

Zhang, Q., Stanier, C. O., Canagaratna, M. R., Jayne, J. T., Worsnop, D. R., Pandis, S. N., and Jimenez, J. L.: Insights into the Chemistry of New Particle Formation and Growth Events in Pittsburgh Based on Aerosol Mass Spectrometry, Environ. Sci. Technol., 38, 4797-4809, 2004.

Zhang, Q., Alfarra, M. R., Worsnop, D. R., Allan, J. D., Coe, H., Canagaratna, M. R., and Jimenez, J. L.: Deconvolution and quantification of hydrocarbon-like and oxygenated organic aerosols based on aerosol mass spectrometry, Environ. Sci. Technol., 39, 4938-4952, 2005a.

Zhang, Q., Canagaratna, M. R., Jayne, J. T., Worsnop, D. R., and Jimenez, J. L.: Time- and size-resolved chemical composition of submicron particles in Pittsburgh: Implications for aerosol sources and processes, J. Geophys. Res.-Atmos., 110, D07S09, doi:10.1029/2004JD004649, 2005b.
Zhang, Q., Worsnop, D. R., Canagaratna, M. R., and Jimenez, J. L.: Hydrocarbon-like and oxygenated organic aerosols in Pittsburgh: insights into sources and processes of organic aerosols, Atmos. Chem. Phys., 5, 3289-3311, 2005c.

Zhang, Q., Jimenez, J. L., Canagaratna, M. R., et al.: Ubiquity and Dominance of Oxygenated Species in Organic Aerosols in Anthropogenically - Influenced Northern Hemisphere Mid-latitudes, Geophys. Res. Lett., 34, L13801, doi: 10.1029/2007GL029979, 2007.

Zhang, Q., Jimenez, J., Dzepina, K., et. al.: Component Analysis of Organic Aerosols in Urban, Rural, and Remote Atmospheres Based on Aerosol Mass Spectrometry, in 7th International Aerosol Conference, St. Paul, Minnesota, 2006.

Zhang, X. F., Smith, K. A., Worsnop, D. R., Jimenez, J., Jayne, J. T., and Kolb, C. E.: A numerical characterization of particle beam collimation by an aerodynamic lens-nozzle system: Part I. An individual lens or nozzle, Aerosol Sci. Technol., 36, 617-631, 2002.

Zhang, X. F., Smith, K. A., Worsnop, D. R., Jimenez, J. L., Jayne, J. T., Kolb, C. E., Morris, J., and Davidovits, P.: Numerical characterization of particle beam collimation: Part II - Integrated aerodynamic-lens-nozzle system, Aerosol Sci. Technol., 38, 619-638, 2004.

Zubkov, M. V., Fuchs, B. M., Eilers, H., Burkill, P. H., and Amann, R.: Determination of Total Protein Content of Bacterial Cells by SYPRO Staining and Flow Cytometry, Applied and Environmental Microbiology, 65, 3251-3257, 1999. 